\title{
Selling the Artist, Not the Art: Using Personal Brand Concepts To Reform Copyright Law for the Social Media Age
}

\author{
Zach Blumenfeld*
}

Introduction: Is This Fine? 242

I. Social Media, the Digital Grateful Dead Model, and Norms of Internet Culture 244

A. Creators Take the Grateful Dead Model Online ................... 244

B. The Wild West of the Influencer World ................................ 248

C. When Artists' Work Goes Viral........................................... 251

D. A Synthesis of Online Norms: From Individual Work to

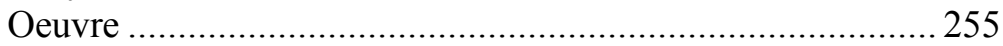

II. Attempts to Fix the Berne Gap ............................................ 257

A. Creative Commons ........................................................... 258

B. Content ID ...................................................................... 260

C. The European Union's Copyright Directive ......................... 262

III. Judge-Made Copyright Reform Using Personal Brand Principles. 264

A. Dastar's Loophole and Reviving Trademark Protection of the Attribution Right ........................................................... 264

B. Hope For the DMCA's Copyright Management Information

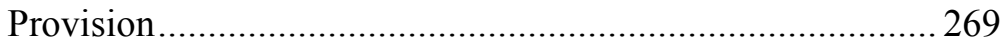

C. Protecting Creators' Economic Power with Takedown-

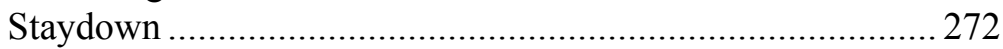

IV. Conclusion: The Positive Feedback of Rights Extension ............ 274 


\section{INTRODUCTION: IS THIS FINE?}

Given the speed at which the Internet churns through content, it is difficult to identify any single online archetype. But if one were to pick a de facto mascot of modern Internet culture, the "This is Fine" dog would be a worthy selection.
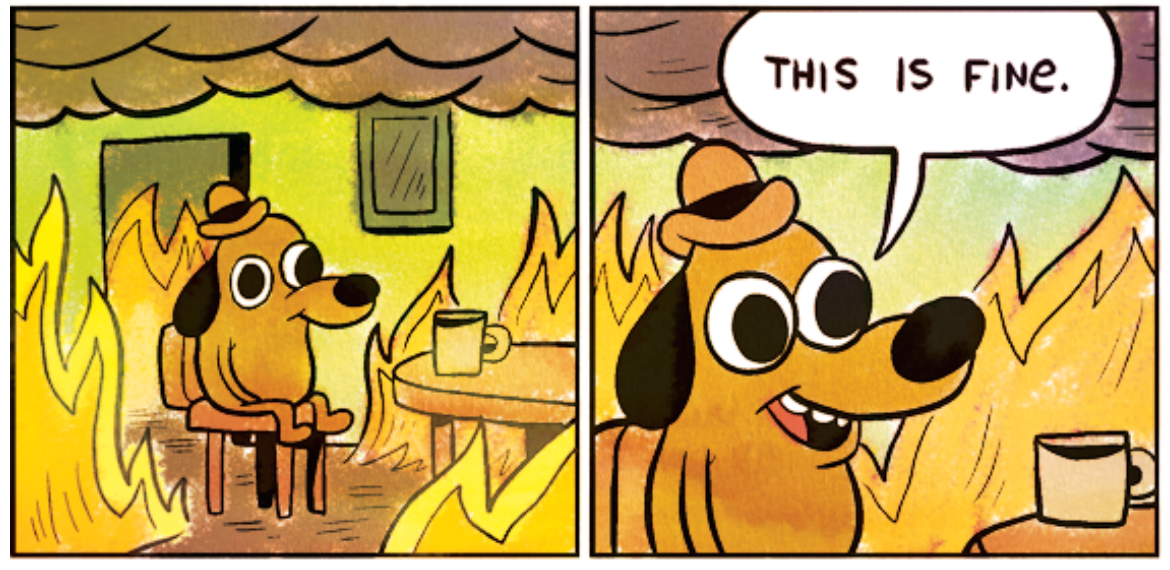

KC Green, excerpt from On Fire, GuNSHOw (Jan. 9, 2013), https://perma.cc/EPP6-ZDA6.

Created by webcomic artist KC Green in 2013 for his Gunshow series, the workactually titled "On Fire"-shows a hatted dog sitting in his burning house, nonchalantly sipping coffee as first his arm and then his face melt off. ${ }^{1}$ Internet users took particular interest in the first two panels of the comic (depicted above), which preserve the dog's blithe indifference to the flames but leave out the grisly ending. By the next year, these two panels had begun to circulate on social media forums such as Tumblr, Imgur, and Reddit, usually posted as a gallows-humor reaction to terrible situations (and typically without attribution to Green). ${ }^{2}$ As the meme grew in popularity, so did attention to Green, whose Gunshow and other projects had attracted enough fans that it was not terribly hard for any interested party to discover the artist behind "This is Fine." Green could sell them prints of the comic, or even plush pillow versions of the infamous dog, through his online store. ${ }^{3}$ He could also direct them to his profile on Patreon, a website that allows culture consumers to fund

* J.D Candidate, Columbia Law School, Class of 2019. Thanks to Professor Jane C. Ginsburg, the JLA editors and staff, and my father for their advice and feedback on this Note, and thanks to all creators who post their work on social media for the inspiration. Find me on Twitter @zachblumy.

1. This Is Fine, KNOW Your MEME, https://perma.cc/HS2Q-P4KE (last visited Feb. 25, 2018).

2. Id.

3. Green's online store also includes "This Is Fine" merchandise such as sweatshirts and mugs. See KC Green, Topatoco, https://perma.cc/8C5U-NCSQ (last visited Feb. 25, 2018).

(C) 2019 Blumenfeld. This is an open access article distributed under the terms of the Creative Commons Attribution License, which permits unrestricted use, distribution, and reproduction, provided the original author and source are credited. 
a creator's endeavors in exchange for some perks. ${ }^{4}$ Perhaps most importantly, Green's success and following garnered him opportunities to work with companies and people who might pay him enough money to make a living drawing webcomics. ${ }^{5}$ His highest-profile client may have been the television network Adult Swim, which paid Green to create an animated version of the full "On Fire" comic for use as an interstitial, a network-branded fifteen-second clip played at the conclusion of commercial breaks. ${ }^{6}$

In 2016, "This is Fine" exploded online, thanks in part to that year's U.S. Presidential Campaign, which was-to put it mildly-unconventional. The Republican Party even used the meme in a tweet upon learning that Hillary Clinton had secured the Democratic nomination. ${ }^{7}$ For ideological reasons, Green was not happy with the Republican Party using his comic, but he took no legal action against the organization, tweeting, "everyone is in their right to use this is fine on social media posts, but man o [sic] man I personally would like@GOP to delete their stupid post." "Rather than suing the Republican Party, Green created a derivative version of "This is Fine," commissioned for physical and online display by political cartoon website The Nib, in which an elephant (the Republican mascot) replaced the familiar dog. ${ }^{9}$ The Nib also paid Green to create an alternate version of the cartoon called "This Is Not Fine," in which the dog frantically puts out the fire and sits in despair at recent events. ${ }^{10}$

In 2017, "This is Fine" was still making the Internet rounds. The day before Donald Trump's presidential inauguration, social media influencer The Fat Jewish (real name Josh Ostrovsky) posted the two panels as a photo on his Instagram account, which has 10.4 million followers. ${ }^{11}$ In the photo appeared the caption "Americans right now," the typeface of which indicates that the photo was likely a screenshot of a tweet. ${ }^{12}$ Ostrovsky's photo, though, does not include attribution to the Twitter user who ostensibly tweeted the panels-and-caption combination. Ostrovsky added the caption, "The next 4 seasons of 'America' are going to be FUCKING NUTS.”'13 Ostrovsky's Instagram post garnered more than 245,000 likes.

4. KC Green Is Creating Comics, PATREON, https://perma.cc/Y3VZ-RMSQ (last visited Feb. 25, 2018).

5. See KC Green, Who, KC GREEN DOT COM DOT COM, https://perma.cc/8H8D-GJ5Q (last visited Feb. 25, 2018).

6. Chris Plante, This Is Fine Creator Explains the Timelessness of His Meme, Verge (May 5, 2016, 9:49 AM), https://perma.cc/M79G-5GQH.

7. GOP (@GOP), TwITTER (July 25, 2016, 2:23 PM), https://perma.cc/N8TM-H2NU.

8. KC Green (@kcgreenn), TwiTTER (July 25, 2016,3:07 PM), https://perma.cc/N5SK-TSZS.

9. The Nib (@thenib), TwITTER (July 25, 2016, 9:10 PM), https://perma.cc/44Y9-NWWF.

10. KC Green, This Is Not Fine, NIB (Aug. 3, 2016), https://perma.cc/5JH8-R4GM.

11. See Josh Ostrovsky (@thefatjewish), INSTAGRAM, https://perma.cc/ZXT6-QPVM (last visited Feb. 25, 2018). Social media influencers are people who gain large followings on various social media platforms (Instagram, Snapchat, Twitter, etc.) and use their popularity and cultural capital to sell products - either the influencer's own products or the products of a third-party brand. See Zach Blumenfeld, I Went to Cancún with Some Social Media Influencers and It Was Fascinating and Terrifying, PASTE MAG. (June 21, 2016, 10:50 PM), https://perma.cc/3V6E-E593.

12. Josh Ostrovsky (@thefatjewish), The Next 4 Seasons of "America" Are Going to Be FUCKING NUTS, INSTAGRAM (Jan. 19, 2017), https://perma.cc/83LB-TD9S.

13. Id. 
"This is Fine" is quite useful in depicting the typical life cycle of modern online artistic culture: its longevity, its ubiquity, and the relative notoriety of its author make it familiar to casual students of the Internet, but the processes underlying its creation and subsequent use are true of countless works posted on the web. ${ }^{14}$ First, an original work is posted online; then, individual Internet users take the work and put it in a new context; finally, if the work garners enough traction, corporate entities and social media personalities (and occasionally the creator themselves) might use it for the purposes of building their brand - a typically commercial act. The troubling part of this process is that any credit the original work's author might have received is often lost in the digital ether along the way. In an Internet climate where social capital and attention from followers are increasingly tied to economic prospectsone hit wonders do not alone pay the bills, but will secure an artist the audience necessary to sell his entire body of work - this loss of attribution can present serious obstacles to the author's ability to make a living off his works. Artists cannot build personal brands without strong attribution rights, and they cannot maintain those brands without the capacity to protect their overall suite of creations.

This Note will argue that American courts should take account of digital works' secondary purpose as personal brand advertisement and treat these works as such, thereby protecting creators' economic interests in a world where social capital is economic capital. In Part I, I explain how Internet creators, ordinary users, companies, and social media influencers operate under the current system of formal copyright law and informal norms. What they appear to want out of an attendant legal regime looks more like personal brand protection, specifically insofar as it encompasses the attribution right and the ability to monetize their whole oeuvre rather than specific content. In Part II, I discuss privately ordered methods of enforcing the rights that creators seem to want, before explaining that these methods are insufficient to meet creators' needs. Finally, in Part III, inspired by recent judicial developments that offer promising interpretations of the Copyright Act, I outline a path to more robust protection of attribution and integrity rights than copyright law has previously afforded.

\section{SOCIAL MEDIA, THE DIGITAL GRATEFUL DEAD MODEL, AND NORMS OF INTERNET CULTURE}

\section{A. Creators Take the Grateful Dead Model Online}

The idea of a creator's personal brand is not new, nor is it unique to digital artists. Many notable film directors develop a signature style that makes their films easily identifiable, regardless of the studio that produced the film. ${ }^{15}$ In hip-hop music, a

14. Remarkably, Green has struck viral gold more than once. Among other noteworthy memes that started as Green webcomics are "Staredad" and the ridiculously named "Dick Butt." See KC Green, KNOW YOUR MEME, https://perma.cc/4XB4-H4JL (last visited Feb. 25, 2018).

15. To name a few examples: J.J. Abrams is known for his use of lens flares; Wes Anderson breaks with film orthodoxy by centering his subjects in the frame; Tim Burton films look and feel Gothic. See 
record's producer will often place a "producer tag" at the beginning of the track so that listeners can identify who made the beat. ${ }^{16}$ These idiosyncrasies not only represent the individuality of the author, they are also a convenient way to build a creative brand. The creator seeks to give his fans some idea of what to expect with each new work and hopes that these fans will spend money and/or time consuming it.

In the traditional entertainment model, creators hoping to make a living disseminating their work on a wide scale needed to work with large companies to achieve the necessary resources and distribution. But the advent of social media opened an alternate door for those who cannot (or do not want to) attract the eye of a major film studio or record label. Platforms like YouTube, Facebook, Twitter, and Instagram offer the opportunity for creators to connect directly with the people who might consume their work. YouTube, Tumblr, and Soundcloud function both to connect creators with consumers and to host creators' original content. ${ }^{17}$ And websites like Patreon, Indiegogo, and Kickstarter allow independent creators to crowdfund their projects. ${ }^{18}$ The Internet has democratized entertainment, but a proliferation of tools has not made it any easier for an aspiring artist, singer, or actor to stand out; it has merely changed the nature of the competition. Instead of jockeying for the attention of Hollywood power brokers, New York publishing houses or music moguls, many creators now compete for the attention of fans, replacing the old middlemen with social media platforms.

Over the past decade, social media has morphed from a fun way to communicate and network online into a vast, multibillion-dollar playing field. As of June 2017, YouTube had 1.5 billion monthly users, while Facebook had reached two billion monthly users, nearly one-third of Earth's total population. ${ }^{19}$ And by September, Instagram had rocketed up to 800 million monthly users - a 33\% growth over just an eight-month period. ${ }^{20}$ Despite its news-making power and its status as the unfiltered platform of President Donald Trump, Twitter checks in with a relatively paltry estimated 328 million monthly users. ${ }^{21}$ Not all of these platforms' users are

Danilo Castro, 15 Directors with a Signature Style, SCREENRANT (Mar. 29, 2016), https://perma.cc/BA4L-RSCZ.

16. See Julian McKenzie, Here Are the Top-10 Hip-Hop Producer Tags in the Game, UNDER THE INFLUENCE OF MUSIC (Jan. 29, 2018), https://perma.cc/GS6D-RBJ7.

17. YouTube is beginning to create original content on its own subscription service, YouTube Red. The company will not release its subscriber numbers, but Red's success could open the door for more social media platforms to hybridize into a new generation of studios and labels. See Dade Hayes, YouTube Red Rebooting 'Karate Kid,' Says Subscriber Numbers Are 'On Track', ForBES (Aug. 4, 2017, 2:57 PM), https://perma.cc/N4HW-9JH3.

18. See PATREON, https://perma.cc/ZRJ8-QFC7 (last visited Feb. 25, 2018); Creative Works, INDIEGOGO, https://perma.cc/XSB3-D8CD (last visited Feb. 25, 2018); KICKSTARTER, https://perma.cc/8EDQ-TBKB (last visited Feb. 25, 2018).

19. Josh Constine, Facebook Now Has 2 Billion Monthly Users...and Responsibility, TECHCRUNCH (Jun. 27, 2017), https://perma.cc/WR5D-A72A.

20. Darrell Etherington, Instagram Now Has 800 Million Monthly and 500 Million Daily Active Users, TECHCRUNCH (Sep. 25, 2017), https://perma.cc/7WMZ-KGHS.

21. Kurt Wagner, How Many People Use Twitter Every Day?, ReCoDE (July 27, 2017), https://perma.cc/JJ8L-6WDG. 
individuals; precisely because so many people maintain a social media presence, large corporations and small businesses flock there to advertise. ${ }^{22}$ Companies also pay individual users with large followings to promote goods and services. These people are called influencers, and as a category, they have become powerful enough that Forbes has run a "Top Influencers" series on the most successful of them. ${ }^{23}$ For example, one former Vine and current YouTube star, Logan Paul, commands $\$ 150,000$ per sponsored Facebook post and $\$ 80,000$ per sponsored Instagram content. $^{24}$ Meanwhile, duo Meg Resnikoff and Elle Walker have built a YouTube channel called "What's Up Moms" that commands up to seven figures per corporate partnership. ${ }^{25}$ Other social media influencers have used their clout to launch fashion lines, develop content for entertainment companies, and write New York Times bestselling books. ${ }^{26}$ There is serious money to be made in social media. The more followers someone has on any given platform, the more their overall content is worth - both directly, to their fans, and indirectly, to advertisers and other corporate sponsors. Evidence for the economic value of a social media following lies in the thriving "fake followers" industry, through which users can purchase robot accounts that resemble real people in order to artificially inflate their follower numbers. ${ }^{27}$

With the battle for attention raging, many online creators have turned to a business model in which they attract a following by giving away their creative product for free, then derive the majority of their revenue by leveraging this attention in other ways. The Grateful Dead pioneered this method, allowing fans to distribute bootlegged tapes of their live performances because these unauthorized recordings

22. Corporate social media accounts are fascinating in the variety of tacks they assume in pursuing consumers' attention. For instance, the Tennessee-based dessert snack MoonPie has attracted praise for its absurdist Twitter account, shooting from fewer than 20,000 followers to nearly 170,000 followers thanks to a few immensely popular tweets and its sense of humanness. See Maseena Ziegler, How MoonPie Became the Unexpected Top Social Media Brand of 2017, ForBes (Dec. 20, 2017), https://perma.cc/H7LE-PEW7; MoonPie, SocialBlade, https://perma.cc/G2UM-AT6A (last visited Feb. 25, 2018). By contrast, Cinnabon faced massive outrage after tweeting a "tribute" to deceased actress Carrie Fisher that many perceived to be a tone-deaf promotion of the pastry-maker's brand. See Gene Maddaus \& Lawrence Yee, Cinnabon Deletes Carrie Fisher Tweet After User Outrage, VARIETY (Dec. 27, 2016), https://perma.cc/VXZ9-3TMQ.

23. Top Influencers, FORBES, https://perma.cc/7MSZ-CFB2 (last visited Feb. 25, 2018).

24. Logan Paul, ForBES, https://perma.cc/U34A-8PT7 (last visited Feb. 25, 2018). Note that these numbers may have changed since Paul posted a video of a corpse he found in Japan's "Suicide Forest" that sparked outrage and caused YouTube to temporarily remove him from its highest advertising tier. See Emma Kidwell, Logan Paul (and the Internet) Need to Stop Treating Japan as Clickbait, Verge (Jan. 11, 2018), https://perma.cc/8NW7-EX6P.

25. Clare O'Connor, Forbes Top Influencers: How What's Up Moms Turned Viral Videos into a Media Company, FoRBES (Sept. 26, 2017), https://perma.cc/XD35-5V47.

26. See Karen Kay, Millennial 'Influencers' Who Are the New Stars of Web Advertising, GUARDIAN (May 27, 2017), https://perma.cc/TH72-C3LM; Brian Zuercher, Social Influencers: Coming Soon to a Media Company Near You, ADWEeK (Aug. 25, 2017), https://perma.cc/L6Q6-FQ98; Thu-Hong Ha, You Can Thank Facebook, Hulu, and Instagram for Some of the Year's Bestselling Books, QUARTZ (Dec. 18, 2017), https://perma.cc/EPJ7-CVKX.

27. See Nicholas Confessore, Gabriel J.X. Dance, Richard Harris \& Mark Hansen, The Follower Factory, N.Y. TimES (Jan. 27, 2018), https://perma.cc/MZB8-SYVD. But see Jake Kosakowski, No Value in Fake Followers, N.Y. TIMES (Feb. 4, 2018), https://perma.cc/CT6B-6CF8 (arguing that engagement with real social media followers is far more valuable than purchasing fake ones). 
would simply increase the size and devotion of the group's fandom - the "Dead Heads"- who would spend their time and money following the band on tour and buying its merchandise. ${ }^{28}$ Today, the "attention economy" and other realities of online commerce, including the ease with which creative works can be copied and distributed for free and without authorization, have made the Grateful Dead model far more common, particularly among musicians, performers, and visual artists. ${ }^{29}$

If $\mathrm{KC}$ Green is a modestly successful poster child for this Internet-centric version of the Grateful Dead model, Chancelor Bennett, professionally known as Chance the Rapper, is its golden boy. The Chicago-based rapper released his first two mixtapes, "10 Day" and "Acid Rap," for free on digital download and streaming services in 2012 and 2013, respectively. They garnered him a significant following and critical acclaim. "After I made my second mixtape and gave it away online, my plan was to sign with a label and figure out my music from there," he told Vanity Fair in a 2017 interview. "But after meeting with the three major labels, I realized my strength was being able to offer my best work to people without any limit on it." ${ }^{30}$ Rather than signing with a label, Chance concentrated on touring and selling merchandise. And while music remained at the core of his vocation, its role in his business model was as a promotional tool to sell other forms of intellectual property. This strategy completely reversed the traditional framework, wherein musicians toured to support record sales. Chance's business model was accompanied by an increased legal focus on trademark suits enjoining the sale of bootlegged or fake merchandise. ${ }^{31}$ Today, Chance the Rapper remains independent, interspersing new music releases with periodic concerts, daily interaction with his more than seven million Twitter followers, and regular updates to the merchandise offered on his website. ${ }^{32}$ Combined with income he has accumulated from partnerships with companies like Apple and Kit Kat, touring and merchandise revenue has helped Chance's net worth reach $\$ 33$ million as of $2017 .^{33}$

The underlying principles of the online Grateful Dead model can be applied to all Internet-focused creators. Chance the Rapper could attract attention because fans

28. Joshua Green, Management Secrets of The Grateful Dead, ATLANTIC (Mar. 2010), https://perma.cc/P55M-FRWK.

29. See generally Tim Wu, The AtTEntion Merchants (2016). Note that the Grateful Dead model doesn't work for every type of artist, particularly photographers and literary authors. A solution addressing these creators' needs is discussed in Part III(B) of this Note.

30. Lisa Robinson, Why Chance the Rapper Makes Music for Free (and How He Actually Makes Money), VANITY FAIR (Feb. 2017), https://perma.cc/5G25-57WV.

31. Chance the Rapper Sues Bootleggers Over Fake Merchandise, CBS CHICAGO (Apr. 21, 2017), https://perma.cc/VDU9-XRND.

32. SHOP - CHANCE THE RAPPER, https://perma.cc/YT57-DAAF (last visited Feb. 25, 2018).

33. Chance the Rapper, FORBES, https://perma.cc/C96X-ZHW2 (last visited Feb. 25, 2018). While it is unclear how many Chance the Rapper-level musicians the market can support via touring and merchandise, note that both revenue streams are on the rise; music merchandise revenues hit $\$ 3.1$ billion in 2016, increasing $10 \%$ from the previous year, and live music revenue accounted for more than half of the total music industry in 2017. See David Browne, Inside Music's Merch Gold Rush, Rolling STONE (Feb. 6, 2018), https://perma.cc/93YW-G75Q; see also Paul Resnikoff, Live Concerts + Streaming $=73 \%$ of the US Music Industry, Digital Music News (June 7, 2017), https://www.digitalmusicnews.com/2017/06/07/music-industry-concerts-streaming. 
knew who was behind the music, which enabled him to monetize the brand he had built. But this does not mean success or even financial viability follows. Just as not every webcomic artist is KC Green, the vast majority of musical artists are not Chance the Rapper; the personal branding business model does not lead to profit unless it is paired with skilled fan interaction and high-quality artistic work. Moreover, the process is slightly different for visual artists and illustrators - or any social media influencer who posts original content to YouTube or Instagram - whose brand is built on images and whose branded merchandise therefore should be intrinsically intertwined with their copyrighted IP. These creators might rely more heavily upon statutory protections than might musicians. The process is different still for photographers, reporters, and other creative professionals whose specific creative product does not lend itself as well to constructing a fan base. For these creators, the norms attendant to personal branding are less relevant, and the more traditional business model of selling individual works must prevail. ${ }^{34}$

In the remainder of this Part, I investigate some of the informal protective norms that have developed in the online communities of these various types of creators and determine the rights that appear most important to them.

\section{B. THE WILD WeSt OF THE INFLUENCER WORLD}

The effect of informal norms on online creators' content is inconsistent, particularly temporally. ${ }^{35}$ For instance, YouTubers PewDiePie and Logan Paul received significant backlash for committing faux pas - the former made numerous racist and anti-Semitic comments in his video game playthrough videos, while the latter uploaded an irreverent video of a dead body from Japan's "Suicide Forest." Both felt the consequences in their pocketbook; PewDiePie lost a potentially lucrative partnership with Disney and YouTube cancelled a deal for original content with Paul. ${ }^{36}$ But for each influencer, there does not seem to have been a tremendous impact on either one's ability to generate revenue on his own social media channels, as they have each retained massive followings and their places among the most important of their peers. ${ }^{37}$ Cynics would argue that once the most recent negative wave of bad press dies down, PewDiePie and Paul will have little trouble attracting

34. With respect to photographers, Instagram has emerged as a powerful tool to build a niche fan base. See Samuel Zeller, 10 Instagram Tips for Photographers, PetAPIXel (Oct. 24, 2016), https://perma.cc/J8FF-5NLW; Robin Ryan, 12 Steps to Successfully Promote Your Photography on Instagram, Digital PHOTOGRAPHY SCHOOL, https://perma.cc/6FDY-D8BZ (last visited Feb. 25, 2018). Nonetheless, photographers still require copyright protection to prevent potential clients from using their works for free.

35. Interestingly, one area in which informal norms on social media are quite powerful is the fashion industry, where the practice of "shaming" design copyists has found some success. See David Yi, How Social Media Shaming Controls Fashion Copycats, MASHABle (Mar. 15, 2016), https://perma.cc/T9SN-58LL.

36. Olivia Solon, Disney Severs Ties with YouTube Star PewDiePie over Antisemitic Videos, GuARDiAn (Feb. 14, 2017), https://perma.cc/DF9L-ZEVT; Luke Plunkett, YouTube Removes Logan Paul from Google Preferred, Puts Other Projects on Hold [Updated], KоTAKU (Jan. 10, 2018), https://perma.cc/85S9-JV6Z.

37. Top Influencers, supra note 23. 
corporate partnerships. Thus far the evidence bears out this view-less than a year after the Suicide Forest controversy, YouTube released the film The Thinning: New World Order, in which Paul stars. ${ }^{38}$

Norms concerning what can be said online are entirely separate from norms concerning how to credit those who have said it, but the result is largely the same. The cases of notable influencers Ostrovsky and Elliot Tebele (who goes by FuckJerry on social media) are illustrative of how attribution works on platforms with lax enforcement policies. In 2015, Ostrovsky faced multiple well-founded allegations of stealing jokes from other online personas and comedians. ${ }^{39}$ When asked about one particular joke he had posted on his Instagram without attribution to its author, Ostrovsky replied, "I was drinking a daiquiri nude and looking at the internet, and honestly, I didn't know where it came from." ${ }^{\text {" }}$ This nonchalant attitude toward proper attribution appears to be on-brand for Ostrovsky, whose ventures include a wine called "White Girl Rosé," and it also appears to have carried him to continued success more than two years after the fact. ${ }^{41}$ A quick glance at Ostrovsky's Instagram profile reveals that very few of the joke-photos he posts to the platform carry attribution to their source. Only three of his twelve most recent posts as of January 4, 2018 identify this information. Looking at Ostrovsky's Twitter account confirms that he did not merely cross-post his original content between platforms. ${ }^{42}$ Instagram's Community Guidelines require users not to "post anything [they]'ve copied or collected from the Internet that [they] don't have the right to post." 43 So long as the tweets Ostrovsky is reposting are copyrightable, it appears he is in violation of these guidelines. ${ }^{44}$ And yet, as of 2015, Ostrovsky made $\$ 2,500$ per brand-sponsored post. ${ }^{45}$

The story is similar with regards to Tebele, whose Instagram account FuckJerry and its namesake media company Jerry Media were projected to pull in between $\$ 1.5$

38. Todd Spangler, Logan Paul Gets YouTube Reprieve for 'The Thinning' Movie Sequel, VARIETY (Oct. 17, 2018), https://perma.cc/5CGB-6FCB.

39. Alex Abad-Santos, The Fat Jew's Internet Plagiarism Scandal, Explained, Vox (Aug. 19, 2015), https://perma.cc/3P6C-4PEN.

40. Jesse David Fox, A Conversation With the Fat Jew: 'That's Not Who I Am or What I'm About', VULTURE (Aug. 21, 2015), https://perma.cc/W2LV-85FB.

41. "White Girl Rose 2015," https://perma.cc/95HT-SELV (last visited Oct. 29, 2018).

42. Josh Ostrovsky (@thefatjewish), InSTAGRAM, https://perma.cc/DNE6-TL2B (last visited Jan. 5, 2018); see also The Fat Jew (@FATJEW), TwITTER, https://perma.cc/7WR8-PHUW (last visited Jan. $5,2018)$.

43. Community Guidelines, InSTAGRAM, https://perma.cc/63CX-QMKM (last visited Jan. 11, 2019). Refreshingly, Instagram's Community Guidelines are written in layperson's terms that can be easily understood by any user, not just intellectual property lawyers.

44. The federal courts have yet to create a categorical rule regarding the copyrightability of tweets, but at least some of them likely meet the Copyright Act's requirements for originality and fixationespecially given the increased use of "threads" (multiple connected tweets by the same author) and Twitter's expansion of its character limit from 140 to 280. See Sara Gates, "Going Viral" By Stealing Content: Can The Law Cure The Problem Of Viral Content Farming?, 26 Fordham InTELl. Prop. MEDIA \& ENT. L.J. 689, 728 (2016).

45. Sam Biddle, @TheFatJewish Is A Thief, GAWker (Aug. 17, 2015, 11:05 AM), https://perma.cc/S2PB-BLJM. 
and $\$ 3$ million in $2016 .{ }^{46}$ Like TheFatJewish, FuckJerry thrives on joke and meme curation, and he has therefore faced many of the same criticisms. ${ }^{47}$ Since the 2015 firestorm surrounding his accounts settled down, Tebele has taken to regularly crediting the sources of the comedic bits he finds on the Internet, typically in the comments of his Instagram posts if not within the image itself. ${ }^{48}$ His opinions on the legality of his curation is similar to Ostrovsky's, albeit less overtly flippant:

It's such a bizarre thing, this meme culture . . There's no way to find the origins of who started it. It's a free-for-all jungle. I've tried to find the original post. I get people saying that others are getting famous for other people's content. But it's curating the best of meme culture. ${ }^{49}$

Tebele has something of a point. Even now that he has begun citing his sources, he has no way of knowing whether the sources own the underlying expression or are merely reposters themselves. Granted, the problem seems much more difficult to solve regarding text-based posts than images; there is less certainty about the former's copyrightability, particularly given the brevity of tweets and Instagram captions. Similarly confounding the issue, metadata attaches only to images, not to text typed directly into these social media platforms. ${ }^{50}$ As a partial solution, Twitter has sometimes "withheld" tweets in response to DMCA complaints. ${ }^{51}$

This leaves the comedy community's powerful norm against joke stealing as perhaps the best tool for aspiring funny people to use for content and brand protection. Professors Dotan Oliar and Christopher Sprigman described the ways in which this norm has grown to fill gaps in copyright law among the stand-up comedy community, pointing out certain elements of this informal protection regime that differ from traditional copyright. ${ }^{52}$ Enforcement of these norms typically occurs either through jabs at the offender's reputation or refusal to work with a known joke

46. Madeline Berg, How FuckJerry Wants to Go from Instagram To Empire, FoRBES (Apr. 8, 2016, 10:15 AM), https://perma.cc/ELG3-P38B.

47. Marah Eakin, Shitty Instagram Accounts the Fat Jew, Fuck Jerry Still Stealing Comedians' Jokes, A.V. CLuB (Aug. 3, 2015), https://perma.cc/2E84-QDE6.

48. Zoë Henry, How FuckJerry Turned an Instagram Account into a Multimillion-Dollar Business, INC. (Oct. 4, 2017), https://perma.cc/B7AS-FTEG. Nonetheless, Tebele still occasionally finds himself in hot water regarding attribution. See KMarko, Meme Stealer "Fuck Jerry" Starts a Fight with Barstool, Lasts About 15 Minutes in the Octagon Before Deleting Twitter, BARSTOOL SPORTS (Feb. 7, 2017), https://perma.cc/ZP5A-2LXY. In this particular instance, Tebele accused the sports-comedy entity Barstool Sports of stealing a joke that he himself had reposted without attribution.

49. David Yi, The Double Tap Couple, MASHABLE (Apr. 5, 2016), https://perma.cc/429L-CBHZ.

50. Short phrases are explicitly excluded from copyright protection; see What Does Copyright Protect?, U.S. COPYRIGHT OFFICE, https://perma.cc/3SGZ-WW8H (last visited Feb. 25, 2018). Whether or not a tweet qualifies as a "short phrase" has yet to be definitively determined.

51. Dante D’Orazio, Twitter Is Deleting Stolen Jokes on Copyright Grounds, Verge (Jul. 25, 2015), https://perma.cc/S8YR-X3ZS. When Twitter does take down tweets in accordance with the DMCA, it posts the notices to the website Lumen (formerly known as Chilling Effects), a database that tracks DMCA takedown notices and watches for abuse of the procedure. See https://perma.cc/K7KUXE99.

52. Dotan Oliar \& Christopher Sprigman, There's No Free Laugh (Anymore): The Emergence of Intellectual Property Norms and the Transformation of Stand-Up Comedy, 94 VA. L. REV. 1787 (2008). One difference between copyright and the informal norms of comedy is that the latter offer protection to both ideas for jokes and their expression. Id. at 1790. 
thief, tactics that tend to be effective within the tight-knit comedy world. ${ }^{53}$ Carlos Mencia, for example, was a breakout star with his own Comedy Central series in 2005; by 2010, after admitting that the myriad joke-stealing accusations against him were true, Mencia's show was canceled, and his reputation and chances for future comedy success were ruined. ${ }^{54}$ Yet even within stand-up comedy, joke theft is not always the death knell for a career. ${ }^{55}$ And on the boundless playing field of social media platforms, which lack the barriers to entry and insular ranks that define the stand-up world, the norms against joke theft become much harder, if not impossible, to effectively enforce - particularly against people who are not members of the old comedy guard. ${ }^{56}$ What remains of the norm against joke stealing is enough to rally the online press against an influencer, but not enough to scare off sponsors or chase away the legions of fans with whom the influencers can communicate directly. So Ostrovsky, Tebele, and the like currently have minimal incentive to properly attribute their material.

\section{When ARTists' Work Goes Viral}

It's largely the same story regarding images on the Internet. When a photograph or piece of artwork becomes the background for a meme, informal online norms typically appear to demand acquiescence. The original author can attempt to find other ways to monetize any attention he or she receives, but unless the work's integrity has been compromised, there is customarily nothing to be done about creditless copying - regardless of how much profit could be made from the meme. Asked if it bothered him that "This is Fine" had been appropriated so many times online, KC Green responded stoically:

It's just the webcomic model that we've all sort of figured out over the years- 'we' meaning other webcomic artists. I have a store through TopatoCo where we sell prints of this comic. I make shirts and stuff. I basically try to monopolize this one image, because, hey, if people want it, I could use it. I sell books of all my work. I have Patreon. ${ }^{57}$ There's always a lot of different things that help me make a living off of what I do. Plus I do a lot of freelance here and there. Sometimes [the television network] Adult Swim comes up to you and says, "Can we animate "This is Fine"?,58

Green's reply takes for granted the notion that fans of "This is Fine" will care enough to find out who he is and make sure to buy from Green's webstore if they choose to purchase meme merchandise. Yet the online marketplace Redbubble sells "This is Fine" mugs, stickers, and t-shirts, designed by independent artists, without so much

53. Id. at $1816-17$.

54. Marijke Rowland, Carlos Mencia's Standup Career Was in Tatters, but He's Back, Modesto BEE (June 12, 2014), https://perma.cc/GHB8-JPSY.

55. Colin Patrick, A Not-So-Funny Look at 6 Comedians Accused of Plagiarism, Mental Floss (Jan. 21, 2016), https://perma.cc/8NF5-R8ED.

56. See Jeremy A. Schachter, That's My Joke ... Art . . Trick!: How The Internal Norms of IP Communities Are Ineffective Against Extracommunity Misappropriation, 12 VA. SPORTS \& ENT. L.J. 63 (2012).

57. Green, supra note 4.

58. Plante, supra note 6. 
as crediting Green, let alone providing a link to his official merchandise distributor or, apparently, paying him royalties. ${ }^{59}$ This suggests that perhaps Green misuses the word "monopolize" in the quote above, or else he simply does not care much about the spread of his image so long as he is able to make a living. The latter stipulation is supported by tweets the webcomic artist wrote after the Republican Party used "This Is Fine": "i still feel like i dont [sic] need to get paid when businesses or the like use memes of my art on social media. thats [sic] just how it goes now." 60 In other words, Green has accepted nonpayment as a norm of meme culture. ${ }^{61}$ His lone quibble is with the use of his work by organizations he dislikes. ${ }^{62}$

These customs apply in more than just Green's case. "Distracted Boyfriend," arguably the most popular meme of 2017, proves especially well-suited for study of what the original creators of viral images might be forced to forgo. ${ }^{63}$ Unlike other meme bases such as "This is Fine," "Distracted Boyfriend" originated as a stock photo that can be found online at its source, an e-marketplace called iStock. ${ }^{64}$ As of October 2018, the site charges $\$ 12$ per download of the photograph, which means it is fairly straightforward to track how much revenue iStock and photographer Antonio Guillem might have brought in had every use been paid. Additionally, iStock's licensing agreement contains certain terms of interest to this analysis. ${ }^{65}$ At item 3(c), the agreement reads, "You may not use content in any way that allows others to download, extract, or redistribute content as a standalone file (meaning just the content file itself, separate from the project or end use)." ${ }^{\prime 66}$ At item 4, the agreement

59. RedBUBBLE.COM, https://perma.cc/SV59-X9KE (last visited Oct. 29, 2018). This particular website provides a notice procedure for copyright infringement that Green could utilize if he knew about the existence of competing merchandise. That the products remain online suggests that Green is rather indifferent to his exclusive economic rights.

60. Aja Romano, Why the GOP Twitter Couldn't Pull off the "This is Fine” Meme, Vox (July 28, 2016), https://perma.cc/Z3N6-ZHCX.

61. Some photographers and distribution companies have attempted to spit into the wind of meme culture. In 2015, Getty Images settled privately with numerous websites that had used the "Socially Awkward Penguin" meme, which riffs on a photo taken for National Geographic and distributed by Getty. See Caitlin Dewey, How Copyright Is Killing Your Favorite Memes, Wash. Post (Sept. 8, 2016), https://perma.cc/9R99-YR2V. As of this writing, however, "Socially Awkward Penguin" is still widely available on the Internet. See, e.g., Socially Awkward Penguin, PINTEREST, https://perma.cc/ATZ8-2PYL (last visited Feb. 25, 2018). Additionally, one of the websites sued by Getty created an illustrated version of the meme and used the opportunity to rub the norms of meme culture in the licensing company's face. See Getty Images demands license payment for Awkward Penguin!, GetDigital, https://perma.cc/QU8W-DW9W (last visited Feb. 25, 2018).

62. Green, supra note 8 .

63. Nathan Heller, The Distracted Boyfriend Meme's Perverse Pleasure in 2017, NEW YORKER (Dec. 11, 2017), https://perma.cc/HRD8-97MG.

64. Disloyal man with his girlfriend looking at another girl - Stock image, ISTOCK, (Nov. 2, 2015), https://perma.cc/L5UK-6CC2 (last visited Feb. 25, 2018).

65. iStock Content License Agreement, ISTOCK (last updated June 2017), https://perma.cc/2EH5Q8EK. As far as terms of service go, this one is a pleasant surprise: easily comprehensible and largely free of jargon.

66. Id. Here, "project or end use" is undefined, which could cause some difficulty in interpretation. The most reasonable interpretation is that if the image is licensed for use in an advertisement or blog post, the licensee is allowed to make the entire advertisement or blog post downloadable. But some questions would still remain. For example, if a website specifically intended for meme creation licensed and 
states that the photo's licensees can transfer the license only to employee, clients, or subcontractors. ${ }^{67}$ The photograph on display at iStock is watermarked by the website, while the photograph as it appears in the meme does not have the watermark - meaning that the meme originated from a legally licensed copy of the photo. So, we can assume that the meme began either when (1) someone made an unauthorized reproduction of a legally licensed copy of the photo or (2) someone licensed and downloaded the photo, then made it publicly available specifically to be turned into a meme. The former seems far more likely than the impractical latter, but in either case, the original licensee has probably violated item 3(c) of iStock's user agreement. Yet as of this writing, there has been no reported breach of contract or copyright action taken by iStock or Guillem - perhaps because they don't mind, cannot determine the legitimate licensee whose copy of the photo spawned the meme, or are deterred by prohibitive litigation costs.

The origin of the meme itself has been tracked down with reasonable confidence: it began in one of a few possible Turkish Facebook groups sometime before late January 2017. ${ }^{68}$ "Distracted Boyfriend" made its way around the Internet before breaking into the mainstream consciousness in August 2017, with the most popular iterations gaining tens of thousands of likes, upvotes, or other platform-dependent marks of approval. ${ }^{69}$ At that point, a number of online publications tracked down Guillem for interview, where he had this to say about the popularity of his stock photograph:

It's not allowed to use any image without purchasing the proper licence in any possible way, so each one of the people that use the images without the licence are doing it illegally. What really worries us and we are not going to allow it, taking the appropriate legal measures, is the use of the images in a pejorative, offensive or any way that can harm the models or me. I'm talking, for example, about the image where their faces are changed by a dog face, a garbage bag, and a dog food bag. ${ }^{70}$

What we thus see is that Guillem is most concerned with protecting his moral rights - specifically, the right to the integrity of his work. By contrast, he appears unperturbed, or at the very least resigned, about the lost potential millions of dollars he and iStock might have earned if they could have enforced the \$12 licensing fee against each individual "memer."

One final example illustrates the priority that artists whose work goes viral place upon moral rights. Comic book artist Matt Furie created Pepe the Frog for his series Boy's Club in the mid-2000s. In the following decade, the smirking amphibian took

downloaded the photo, then posted it on a webpage where the photo and any user-created modifications constituted the "end use," would downloading the image still be a violation of the agreement?

67. Id.

68. On the Origins of the Man Checking Out Another Woman Meme; or, Please Stop Saying It Originates from That Instagram Post, MEME DOCUMENTATION (Aug. 25, 2017), https://perma.cc/2DWL9JSL.

69. Distracted Boyfriend, KNOW YOuR MEME, https://perma.cc/XCV2-ARRX (last visited Feb. 25, 2018).

70. Martin Belam, I Didn't Know What a Meme Was, Says Distracted Boyfriend Photographer, GUARDIAN (Aug. 30, 2017), https://perma.cc/264C-ZLVV. 
its place among the Internet's most ubiquitous memes. ${ }^{71}$ Furie, like Green and Guillem, has appeared mostly unconcerned with the rampant uncredited, unlicensed use of his creation online, saying, "I don't really see it as being something that's negative. It's this almost post-capitalist kind of success. I'm not making any money off of it, but it's become its own thing in Internet culture." ${ }^{\prime 2}$ His primary annoyance in 2015 was that memers had taken to drawing Pepe embracing a character Furie did not create and wearing a different outfit. ${ }^{73}$ These issues would prove paltry compared to the storm of bigotry that yanked Pepe from Furie's control completely: the frog is now classified as a hate symbol, having been appropriated by neo-Nazis and members of the Alt-Right movement. ${ }^{74}$

When Pepe the Frog moved into the mainstream of Internet culture, users of 4chan - the message board known for its large population of online trolls, racists and anti-Semites, and also the birthplace of Pepe as a meme - decided they needed to "take back" Furie's amphibian. ${ }^{75}$ Eventually, and largely with the help and attention of the 2016 U.S. Presidential Campaign, they were able to successfully associate Pepe with nativism, Nazism, and Donald Trump's harsh rhetoric. ${ }^{76}$ In September of that year, the Anti-Defamation League designated Pepe as a hate symbol. ${ }^{77}$ Furie attempted to take back his creation by imploring the public to help him reclaim the frog, but his effort at invoking this informal enforcement of his moral rights ultimately proved unsuccessful. ${ }^{78}$

This failure illustrates the limit of informal, community norms in protecting Internet-famous artists in general and their works in particular. By comparison, consider the plight of Laney Griner, whose photo of her son Sam became the basis for the iconic "Success Kid" meme. ${ }^{79}$ When Griner's husband fell ill and needed a kidney transplant, she was able to utilize the notoriety of Success Kid to crowdfund the associated medical expenses, garnering significant public attention. ${ }^{80}$ The online

71. Pepe the Frog, KNOw Your MEME, https://perma.cc/D77V-YQXA (last visited Feb. 25, 2018).

72. Sean T. Collins, The Creator of Pepe the Frog Talks About Making Comics in the Post-Meme World, VICE (July 28, 2015), https://perma.cc/6753-YLVR.

73. Id.

74. Olivia Nuzzi, How Pepe the Frog Became a Nazi Trump Supporter and Alt-Right Symbol, DAILY BEAST (May 26, 2016), https://perma.cc/2AZG-H88M.

75. Roisin Kiberd, 4chan's Frog Meme Went Mainstream, So They Tried to Kill It, MOTHERBOARD (Apr. 9, 2015), https://perma.cc/QX5J-DBE7. "Take back" is used here in a figurative sense; obviously, 4chan's users have no legal ownership right to Pepe the Frog.

76. Collins, supra note 72.

77. Emanuella Grinberg, Pepe the Frog Designated a Hate Symbol by ADL, CNN (Sept. 28, 2016, 4:35 PM), https://perma.cc/2YGF-XYK3.

78. Matt Furie, Pepe the Frog's Creator: I'm Reclaiming Him. He Was Never About Hate, Time (Oct. 13, 2016), https://perma.cc/Z7ZQ-Z65K.

79. Success Kid/I Hate Sandcastles, KNOw Your MEME, https://perma.cc/84LK-GD8P (last visited Feb. 25, 2018).

80. Matt Silverman, Success Kid's Dad Needs Your Help Getting a New Kidney, DAILY Dot (Apr. 13, 2015), http://perma.cc/2BDX-9JXX. Arguably more important than traditional media coverage was the mobilization of Reddit. See IrishProf, Calling All Redditors: Success Kid's Dad Needs a Kidney. Donate Here:, REDDIT, http://perma.cc/9UH2-K4KC (last visited Feb. 25, 2018). 
community combined to raise more than $\$ 100,000$, far exceeding Griner's goal. ${ }^{81}$ Perhaps the fitting nature of the meme played an important role- "Success Kid" lived up to its name in every sense - but Griner's triumph where Furie failed more likely has to do with the nature of their entreaties. The former was a matter of life or death for a human; the latter "merely" concerned the life or death of Furie's ability to profit from Pepe and protect the work's contextual integrity. The loss of commercial potential is illustrated, for example, by the speed with which fast food chain Wendy's deleted a Pepe meme it tweeted in early 2017; with corporate brands unwilling to touch the cartoon frog, Furie's ability to execute partnerships like the one KC Green formed with Adult Swim is likely destroyed. ${ }^{82}$

With norms insufficient to defend Pepe from those who distorted the frog's purpose, Furie has recently resorted to legal action under the DMCA. ${ }^{83} \mathrm{He}$ has successfully forced the removal of for-profit, Alt-Right-created Pepe products from Amazon and Google Play, and he settled with the author of a Pepe-themed antiimmigrant book to enjoin the book's sale and disgorge the author's profits (which were donated to the Council on American-Islamic Relations). ${ }^{84}$ Furie's efforts to stop Alt-Right personalities from using the meme on social media, however, have yet to reach their conclusion, and the memers, who claim the protection of fair use, have stated their intent to fight the artist's legal action. ${ }^{85}$

\section{A Synthesis of Online Norms: From Individual Work to Oeuvre}

Although the norms governing memes and online content differ somewhat depending on the nature of the work, it is possible to cobble together a combined set of intellectual property protection customs that operates in the social media arena.

The most important norm appears to be that of attribution (or lack thereof). Its enforcement takes place largely in the form of public exposure by a combination of other social media users and online publications. As applied to the artwork behind the non-commercial use of memes, this involves unearthing the original creator and bringing him or her attention, which the creator can then use to monetize the meme

81. Justin's Kidney Transplant, GoFunDME, http://perma.cc/AD9A-FX5R (last visited Feb. 25, 2018).

82. Bryan Menegus, Wendy's Tweets (and Promptly Deletes) a Very Bad Meme [Update: It Gets So Much Worse], GizMODO (Jan. 4, 2017), http://perma.cc/3KRX-UVP3. Note that even though the AntiDefamation League explains that "so many Pepe the Frog memes are not bigoted in nature," the highly visible Alt-Right Internet forces are enough to have tainted the frog's reputation. Pepe the Frog, ANTIDefamation LeAgue, http://perma.cc/HGB7-GALB (last visited Feb. 25, 2018).

83. Matthew Gault, Pepe the Frog's Creator Goes Legally Nuclear Against the Alt-Right, MOTHERBOARD (Sept. 18, 2017, 5:43 PM), http://perma.cc/6WHP-ZC3K.

84. Id.

85. Gault, The Great Meme War II: Amid Lawsuit Threats, the Alt-Right Says Pepe Belongs to Them, MOTHERBOARD (Sept. 19, 2017), http://perma.cc/VN3D-REBU. The fair use issue as applied to non-commercial memes on social media has yet to be fully litigated, due in large part to the propensity of parties to settle. See Lauren Levinson, Adapting Fair Use to Reflect Social Media Norms: A Joint Proposal, 64 UCLA L. REV. 1038, 1056 (2017). As of this writing, Furie's suit against alt-right personality Alex Jones' web company Infowars is set to go to trial in mid-2019. See Brett Barrouquere, Creator of Pepe the Frog Gets Trial Date in Case Against Alex Jones, S. POVERTY L. CTR. (Sept. 13, 2018), http://perma.cc/P4Y3-WS2S. 
via commercial partnerships or direct Internet users to his or her independent, forprofit ventures. As applied to jokes, whether completely original or derived from a meme, the online public seems less concerned with exposing the creator than shaming the copyist, with limited success. Attribution concerns seem to be amplified when the memes or images are co-opted by large entities with many followers, such as influencers, corporations, or political parties.

Another powerful norm exists against the perversion of a work's integrity, notably by its association with disfavored groups or ideologies. This norm does not do much in itself to prevent the misappropriation of a work, but it does help to determine when creators will take legal action to remove infringing copies of their work from the Internet, most notably by way of the DMCA's notice and takedown procedure. Creators practicing tolerance within moral bounds is not unique to the Internet; as early as 1981, George Lucas had adopted a similar policy with regards to Star Wars fanfiction, directing an employee to pen an open letter to fan magazine publishers detailing guidelines for authors wishing to avoid legal action. ${ }^{86}$ Importantly, the norm against perversion of a work's integrity seems to follow from the norm of attribution, as the original author must have a certain amount of online visibility in order to effectively announce their work's informal terms of use to the Internet. ${ }^{87}$

What does not exist, however, is a pervasive norm of vigorously and regularly enforcing the traditional exclusive economic rights granted by American copyright law against non-commercial uses of individual works. This goes not just for the individual creators and writers discussed above, but also for large corporate entities, as memes built on still images from well-known films, television shows, cartoons, and live events have become viral sensations without apparent attempts to shut the process down. ${ }^{88}$ For these sorts of repurposings of well-known cultural artifacts, attribution is not a practical necessity.

Therefore, one can argue that the norms that have emerged online primarily favor protection of the attribution right and of other moral rights - the rights that more closely align with the idea of a creator's brand. While protection of reproduction and distribution rights is still important for many creators to provide a base level of

86. The inciting incident for this open letter was Lucas' encounter with a fanfiction called "Slow Boat to Bespin.” The filmmaker was horrified by the story's sex scene between Han Solo and Princess Leia. See Marc Joly-Corcoran \& Sarah Ludlow, Fans, Fics \& Films... 'Thank the Makers!', in FAN PHENOMENA: STAR WARS 28, 30 (Mika Elovaara ed., 2013).

87. Despite the norm against perversion, counterexamples like that of Pepe the Frog stand out. In Europe, perversions of artists' work by extreme political groups for the purpose of parody is protected. The Court of Justice of the European Union lists two characteristics for protected parody: "[F]irst, to evoke an existing work while being noticeably different from it, and, secondly, to constitute an expression of humour or mockery." Magdalena Jozwiak, No Laughing Matter: The Right to Parody in EU Copyright Law (Case Deckmyn v. Vandersteen, C-201/13), EuR. L. BLOG (Sep. 25, 2014), http://perma.cc/DM3HC44M (citing Deckmyn v. Vandersteen, C-201/13 (Sept. 3, 2014)).

88. See, e.g., Condescending Wonka, KNOW Your MEME, http://perma.cc/6SX5-3EHL (last visited Feb. 25, 2018); Evil Kermit, KNOW Your MEME, http://perma.cc/2QS9-7EH5 (last visited Feb. 25, 2018); Spiderman Pointing at Spiderman, KNOw Your Meme, http://perma.cc/68JX-TTNP (last visited Feb. 25, 2018); One Does Not Simply Walk into Mordor, Know Your MEME, http://perma.cc/6LNN-SY8G (last visited Feb. 25, 2018). One notable exception to this is that of Getty Images containing Socially Awkward Penguin, discussed in note 61, supra. 
financial security, many other creators treat these rights as secondary. An effective scheme geared at artistic brand protection must protect rights that allow for two things: (1) building of a brand and (2) monetization of that brand. ${ }^{89}$ American copyright law does offer some semblance of this protection by way of economic rights, but the current legal structure isn't adequate to serve the brand-based needs that online creators have indicated.

\section{ATTEMPTS TO FIX THE BERNE GAP}

Attribution rights and moral rights are supposed to be protected in every country that has adopted the Berne Convention (hereinafter "Berne"), the leading source of international copyright law. Article 6bis of Berne states the following:

Independently of the author's economic rights, and even after the transfer of the said rights, the author shall have the right to claim authorship of the work and to object to any distortion, mutilation or other modification of, or other derogatory action in relation to, the said work, which would be prejudicial to his honor or reputation. ${ }^{90}$

Many Berne signatories' copyright statutes comply with this requirement explicitly. For example, French law confers upon authors an inalienable and perpetual right to "respect for [their] name, [their] authorship and [their] work."91 The United Kingdom also includes the right to integrity and the attribution right in its copyright statute, although the latter must be asserted by the author in writing. ${ }^{92}$ In Canada, meanwhile, the attribution right is recognized "where reasonable in the circumstances" in association with the exercise of an economic copyright right, and the right to integrity of an author's work receives automatic protection. ${ }^{93}$ The Canadian right to integrity appears particularly well-molded to the norms online creators have developed regarding misappropriation of their works, explicitly stating that moral rights are violated if a work is "used in association with a product, service, cause or institution" in such a way that is "to the prejudice of its author's or performer's honour or reputation." 94

The United States, despite being a Berne signatory, confers explicit attribution rights upon only one group of copyright owners: the Visual Artists Rights Act of 1990 (VARA) applies to its namesake group, both protecting the attribution right and

89. While KC Green and Matt Furie might not place much importance on strengthening their ability to monetize their works, doing so would certainly help them; more crucially, it would improve the financial prospects of photographers and other, less famous digital artists.

90. Berne Convention for the Protection of Literary and Artistic Works, Sept. 9, 1886, art. 6bis, S. Treaty Doc. No. 27, 99th Cong., 2d Sess. 41 (1986).

91. Code de la Propriété Intellectuelle art. L 121-1 (Fr.).

92. See Copyright, Design \& Patents Act, 1988, Part I, Ch. IV, §§ 78-2, 80-1 (U.K.).

93. Canada Copyright Act, R.S.C. 1985, c. C-42. There does not appear to be much case law elaborating upon what qualifies as "reasonable in the circumstances."

94. Id. 
prohibiting false attribution. ${ }^{95}$ VARA's scope is quite narrow, because the Copyright Act's definition of a work of visual art limits the category to works of which there are fewer than 200 copies. ${ }^{96}$ The legislative history of VARA clarifies that Congress intended to stand by this narrow definition when granting attribution rights. ${ }^{97}$ No other category of copyright owners receives any form of explicit attribution right. Indeed, when Congress passed the Berne Convention Implementation Act of 1988 (BCIA), it made no changes to the existing Copyright Act to create a blanket protection for moral rights. ${ }^{98}$ At the time, Congress claimed that the attribution right and other moral rights receive protection via "various provisions of the Copyright Act and Lanham Act, various state statutes, and common law principles such as libel, defamation, misrepresentation, and unfair competition, which have been applied by courts to redress authors' invocation of, the right to claim authorship or the right to object to distortion." ${ }^{99}$ But the resulting hodgepodge of law hasn't operated the way Congress anticipated. Professor Jane Ginsburg notes that

U.S. law ... simply does not afford a substantive equivalent to the Berne Convention's affirmative attribution rights. At best, VARA grants a very incomplete attribution right ... trademark law may still allow an action against passing off, but there is no general right to be recognized as a creator of the work that an author may enforce against nonparties to a contract. ${ }^{100}$

In the absence of legal avenues to protect artists' personal brands, some online communities have turned to private ordering as an alternative. Thus far, two solutions have shown particular promise: Creative Commons and YouTube's Content ID.

\section{A. Creative Commons}

One option that creators currently have to protect attribution rights is utilizing a Creative Commons license. Creative Commons, the organization that provides these licenses, describes them as such:

Every license helps creators-we call them licensors if they use our tools-retain copyright while allowing others to copy, distribute, and make some uses of their workat least non-commercially. Every Creative Commons license also ensures licensors get the credit for their work they deserve. Every Creative Commons license works around the world and lasts as long as applicable copyright lasts (because they are built on copyright). These common features serve as the baseline, on top of which licensors can

\footnotetext{
95. 17 U.S.C. $\S 106 \mathrm{~A}(\mathrm{a})(1)$.

96. 17 U.S.C. $\$ 101$.

97. H.R. REP. NO. 101-514, at 9 (1990).

98. 17 U.S.C. App'x K.

99. S. REP. NO. 100-352, at 9-10 (1955).

100. Jane Ginsburg, The Most Moral of Rights: The Right to be Recognized as the Author of One's Work, 8 GEO. MASON J. INT'L COM. L. 44, 59 (2016).
} 
choose to grant additional permissions when deciding how they want their work to be used. $^{101}$

These additional permissions can include a prohibition on commercial use of the work ("NonCommercial"), a prohibition on creation of derivative works ("NoDerivatives"), and/or a provision that only allows users to distribute or display the work on the exact same terms as the author dictated for use of the work ("ShareAlike"). ${ }^{102}$ Combining the attribution mandate with the restrictions on commercial use and derivative works creates a protective scheme that resembles the norms discussed in Part I of this Note, with the derivative works prohibition functioning to deter at least some distortions of a work's integrity. The Creative Commons website even features a tool that allows authors to easily attach copyright management information-bearing metadata to their works, so that the attribution right is easier to enforce. ${ }^{103}$

But there are issues with Creative Commons licenses, first and foremost being the ability to enforce them in court. The most notable decision thus far concerning anything related to Creative Commons has been Jacobsen v. Katzer, where the court ruled that an open source software license contained "enforceable copyright conditions" because the attribution right upon which the license was conditioned bore a direct relationship to the creator's economic benefit, thus constituting consideration and making the license a valid contract. ${ }^{104}$ No other U.S. Court of Appeals has ruled similarly (or at all) on a Creative Commons or similar open license case, and at least one district court citing Jacobsen has taken issue with its acknowledgement of the attribution right's economic impact. ${ }^{105}$ If future judicial decisions hold that Creative Commons licenses' attribution provision is not a condition of the license but is instead a covenant, then plaintiffs in actions involving these licenses would not have ready access to injunctive relief or statutory damages under the Copyright Act - they would only be able to pursue claims for breach of contract, and only when they could show that the "licensee's failure to comply with the terms of the license has caused demonstrable economic harm to the creator or economic benefit to the licensee." 106 And with principles of unfair competition

101. Licensing Considerations, CREATIVE COMmOns, http://perma.cc/Y3W6-32MW (last visited Feb. 25, 2018) (emphasis added).

102. Licensing Types, Creative Commons, http://perma.cc/W4LT-8W99 (last visited Feb. 25, 2018).

103. Have a Web Page?, CREATIVE COMMONS, http://perma.cc/2CQP-D3AZ (last visited Feb. 25, 2018). Copyright management information and metadata are discussed in greater detail in Part III(B) infra.

104. Jacobsen v. Katzer, 535 F.3d 1373, 1381-83 (Fed. Cir. 2008). Creative Commons filed an amicus brief in support of Jacobsen and in solidarity with the open source license he had used.

105. Philpot v. Media Res. Ctr. Inc., 279 F. Supp. 3d 708, 720 (E.D. Va. 2018) (“[H]arm caused by lack of attribution is not generally cognizable under the Copyright Act.").

106. Ashley West, Little Victories: Promoting Artistic Progress Through the Enforcement of Creative Commons Attribution and Share-Alike Licenses, 36 FLA. ST. U. L. REV. 903, 915 (2009). 
currently shut off to copyright claims, such a road might be difficult to travel for creators trying to enforce their personal brand. ${ }^{107}$

More importantly, Creative Commons licenses might not be well-suited to anyone seeking to monetize individual works within their creative brand, because not even the most restrictive form of the license reserves for a work's author the exclusive rights to reproduction, distribution, public performance and display, and creation of derivative works. So, while webcomic artists and musicians (and any type of creator likely to develop a fan base) might benefit from greater usage of Creative Commons licensing, stock photographers like Antonio Guillem might not. Although the online community would generally like attribution rights and some protection of their works' integrity, allowing the more blasé (if pragmatic) principles of webcomic artists like KC Green to dominate private ordering over the concerns of photographers would not serve each group's priorities equally well.

Meanwhile, the proliferation of Creative Commons licenses could also harm small web publishers, particularly those involved in news reporting or education, which depend on fair use to exploit photos without getting a license. The Supreme Court has acknowledged that commercial use of copyrighted material may still be fair, dependent on the context of the use. ${ }^{108}$ But the "non-commercial" term that may be included in Creative Commons licenses would allow for a successful breach of contract action - that is, a plaintiff could win significant damages against small publishers, putting a significant enough of a dent in their finances to chill use of copyrighted works overall on these sites. ${ }^{109}$

\section{B. Content ID}

Another potential solution to emerge from private ordering, one that applies regardless of a creator's brand potential, is YouTube's Content ID system, first implemented in 2007. ${ }^{110}$ Every time a new video is uploaded to YouTube, the site automatically scans the video and compares it with a database of copyrighted content already available on the platform; if there's a significant enough match with a copyrighted work, YouTube will inform that work's owner, who can then choose to block the new video, lay claim to the creator's share of ad revenue from the new video, and/or track the new video's viewership statistics. ${ }^{111}$ Like Creative Commons, Content ID seems to mesh to some degree with the existing brandfocused norms that online creators seem to favor. For example, if Matt Furie had

107. See infra Part III.A for a discussion of Dastar Corp. v. Twentieth Century Fox Film Corp., 539 U.S. 23 (2003), the case responsible for the current rigid distinction between copyright and unfair competition law.

108. See Campbell v. Acuff-Rose Music, 510 U.S. 569, 585 (1994).

109. Creative Commons licenses are contracts and are thus governed by contract law. See Drauglis v. Kappa Map Grp., LLC, 128 F. Supp. 3d 46, 53 (D.D.C. 2015). But note that because Creative Commons is built on copyright, fair use defenses may still apply. See, e.g., Philpot, 279 F.Supp.3d at 713.

110. David King, Latest Content ID Tool for YouTube, Google Official Blog (Oct. 15, 2007), https://perma.cc/7LH2-RUZH.

111. How Content ID Works, YouTUBE HeLP, https://perma.cc/G92E-BAAW (last visited Nov. 8, 2018). 
created a Pepe the Frog animated short that was then doctored and appropriated by an Alt-Right personality, and if both videos appeared on YouTube, Content ID might catch the similarity, and Furie would have the option to preserve his work's integrity by blocking the Alt-Right derivation. Similarly, a video version of the "Distracted Boyfriend" photograph posted by Antonio Guillem, if it became viral like the still did, could be monetized by the photographer such that he would make up for any lost licensing fees. One particularly interesting case to consider here is that of "Redbone," a song by recording artist Childish Gambino that became the basis for a meme in 2017. ${ }^{112}$ "Redbone" was remixed on both Twitter and YouTube, but it appears that only the Twitter remixes have been removed due to copyright claims. ${ }^{113}$ Many of the YouTube versions of the meme, on the other hand, remain intactpossibly because of the monetization option offered by Content ID, which isn't available on Twitter. ${ }^{114}$

As with Creative Commons, there are problems with Content ID. The biggest issue for creators regarding Content ID is that not all of them receive access to the feature. ${ }^{115}$ YouTube determines who is eligible for Content ID based upon "an evaluation of each applicant's actual need for the tools. Applicants must be able to provide evidence of the copyrighted content for which they control exclusive rights." 116 This process tends to favor large copyright holders that have the institutional tools for providing the requisite evidence of rights ownership. ${ }^{117}$ Content ID also has historically had problems with over-removal of original content. For example, the Let's Play video game streaming community has been disproportionately affected due to its use of copyrighted gaming content. ${ }^{118}$ The

112. Redbone, KNOw Your MeME, https://perma.cc/JC7P-4ZCZ (last updated May 24, 2017).

113. Id.

114. See, e.g., meamer, What Redbone Would Sound Like if You Were Wearing Sweatpants, YouTUBE (June 3, 2017), https://perma.cc/J699-C6F9. Other social media platforms, including Facebook, Dailymotion, and Vimeo, also implement Content ID or similar services, although these other platforms do not allow for monetization. See generally Frequently Asked Questions, AUDIBLE MAGIC, https://perma.cc/3XYZ-FCC9 (last visited Nov. 8, 2018); Billboard Staff, Facebook Tackles 'Freebooting' with Rights Manager Tool, BILlBOARD (Apr. 13, 2016), https://perma.cc/TMG6-WEU9; Content Protection, DAILYMotion, https://perma.cc/3LXV-Z54Y (last visited Nov. 8, 2018); Danny Greer, Vimeo Launches ContentID - Is Your Music Flagged on Vimeo?, PREMIUM BEAT: The BeAt (May $22,2014)$, https://perma.cc/2RDN-VUTR. It is unclear why Twitter has not implemented something similar to Content ID.

115. Discriminatory access to Content ID might well serve an ulterior motive for YouTube by preventing the service from becoming a "standard technical measure" of copyright protection, as defined by 17 U.S.C. $\S 512(\mathrm{i})$ (2012): such measures must be "available to any person on reasonable and nondiscriminatory terms" to count under the statute. $\S 512(\mathrm{i})(2)(\mathrm{B})$. If Content ID were to become a standard technical measure for YouTubers, YouTube's interference with its use could deprive it of safe harbor protection as per $\S 512(\mathrm{i})(1)(\mathrm{B})$.

116. Qualifying for Content ID, YOUTUBE HELP, https://perma.cc/N4EK-AX52 (last visited Nov. 8, 2018).

117. Jonathan, How to Get Your Music into Content ID, Future OF Music COALITION (May 17, 2016, 12.32 AM), https://perma.cc/7928-72CJ.

118. Allegra Frank, Youtube Is Changing the Content ID System in an Effort to Help Creators, PolygON (Apr. 28, 2016, 4:19 PM), https://perma.cc/R76C-BJZ7. In response to this issue, and with a growing Let's Play community demanding change, YouTube made adjustments to Content ID in 2016, allowing game-streaming channels to continue to collect ad revenue during the claim dispute process. Id. 
"Redbone" meme, although it has survived on YouTube, might well contain many instances of fair use, but an automatic process like Content ID cannot even consider this possibility before flagging content. ${ }^{119}$

But if the goal of Content ID is to strike a balance between protecting copyright owners and encouraging a healthy remix culture, then the tool's most pressing problem is that its monetization option is all-or-nothing: either the copyright owner or the second comer profits from the video, but not both. Meanwhile, YouTube retains its forty-five percent share of revenue from the video. ${ }^{120}$ So if the goals of copyright law for online creators should be both to promote brand awareness and enable monetization of that brand, Content ID is at best an imperfect tool, missing out on the potential to incentivize more remixes. Its potential remains seductive, particularly if its protection is extended to more creators on more platforms and revenues are distributed more fairly between the original creator and the second comer - with the platform taking a pay cut — but it is difficult to see why any social media platform would willingly accept a smaller slice of the pie.

In sum, Creative Commons licenses and Content ID have valiantly attempted to serve the needs of all creators in the modern digital economy, but the former does not do enough to protect the economic rights that are key to sustaining a personal brand, and the latter largely functions to selectively protect the economic interests of powerful copyright owners and YouTube while leaving smaller-scale creators (and fair users) out in the cold. Neither can be fully relied upon fully to establish a friendlier environment for artists to establish their personal brands and sell their bodies of work. $^{121}$

\section{The European Union's Copyright DiRective}

The United States has yet to supplement privately ordered solutions like Creative Commons and Content ID with any new legislation protecting creators' rights online. The European Union, however, has recently taken major legislative steps on this front. The European Parliament voted to approve the Directive on Copyright in the Digital Single Market (colloquially and hereinafter the "Copyright Directive") in September 2018, and while the legislation still must pass another vote sometime in

119. Lauren D. Shinn, Youtube's Content Id as a Case Study of Private Copyright Enforcement Systems, 43 AIPLA Q.J. 359, 375-77 (2015).

120. Paul Tassi, The Injustice of the YouTube Content ID Crackdown Reveals Google's Dark Side, FORBES (Dec. 19, 2013, 10:00AM), https://perma.cc/LX4A-T48R.

121. Other content protection tools have more extensive problems. For example, the service Exif forces a credit-giving watermark onto images whenever users attempt to download them. See EXIF, https://perma.cc/6XC8-A88T (last visited Nov. 8, 2018). But this service "is a failed concept for a number of reasons," including the following: (1) "it relies on an assumption that the marketplace is willing to use embed codes rather than to use image files"; (2) “[b]y disabling 'right click' and 'save as,' the technology prevents the public from accessing the embedded metadata of the image file, which is often packed with CMI"; and (3) "[t]he embed codes do not work on social media." Email from Jeff Sedlik, President and CEO, PLUS Coalition, to Nancy Wolff, Partner, Cowan, DeBaets, Abrahams \& Sheppard LLP (Feb. 22, 2018) (on file with author). 
the spring of 2019, observers say the Copyright Directive will likely become law. ${ }^{122}$ Most relevant to this Note is the Copyright Directive's Article 13, which requires "online content sharing service providers" to agree to licenses with rights holders for any content that is shared on the service providers' platforms and, when such a license is not granted, commands the service providers to "cooperate in good faith in order to ensure that unauthorized protected works or other subject matter are not available on their services. ${ }^{123}$ Effectively, social media platforms like Facebook, Twitter, and Instagram must take action to remove infringing content from their platforms or else face liability for copyright infringement.

Article 13 would be an enormous help to creators seeking to protect their copyrighted works. Rather than tracking down individual infringers who might be too numerous or too expensive to sue, creators could instead bring legal actions against the easily identifiable, deep-pocketed Internet companies that host the content. The increased threat of suit, when added to the affirmative oversight responsibilities Article 13 assigns to the social media platforms, might spur the platforms to fund the creation of a definitive online database of copyrighted works. This is precisely what happened to music streaming services over the past halfdecade; facing multibillion-dollar lawsuits over unpaid mechanical royalties, the streaming services agreed to fund a database and royalty-distributing body called the "mechanical licensing collective" ("the MLC"). ${ }^{124}$ The MLC was established as part of the Music Modernization Act passed by Congress in October 2018. ${ }^{125}$

Critics of the Copyright Directive's Article 13 argue that the proposed legislation goes too far in protecting copyright, pejoratively referring to it as the "upload filter." 126 In a letter bearing such signatories as Wikipedia co-founder Jimmy Wales and World Wide Web inventor Tim Berners-Lee, the Electronic Frontier Foundation claims that the law would "requir[e] Internet platforms to perform automatic filtering [of] all of the content that their users upload," turning the Internet "into a tool for the automated surveillance and control of its users" and placing an expensive burden on smaller platforms that can't afford to implement effective filtration mechanisms. ${ }^{127}$ Such a burden might serve to dampen competition among Internet companies and allow "established platforms" to "quietly consolidat[e] their position through a de

122. James Vincent \& Russell Brandom, Everything You Need to Know About Europe's New Copyright Directive, VERGE (Sept. 13, 2018, 2:14 PM), https://perma.cc/YEQ4-RKEK.

123. Amendments Adopted by the European Parliament on the Proposal for a Directive of the European Parliament and of the Council on Copyright in the Digital Single Market, at 56-58, COM (2016) 0593 - C8-0383/2016 - 2016/0280(COD) (Sept. 12, 2018), https://perma.cc/C3R9-KTCH.

124. See Andrew Flanagan, A Music Industry Peace Treaty Passes Unanimously Through Congress, NPR (Sept. 19, 2018, 5:17 PM), https://perma.cc/BY4P-56YJ.

125. See 17 U.S.C.A. § 115(d)(3) (Westlaw through Pub. L. No. 115-277 (excluding Pub. L. Nos. 115-232, 115-271)).

126. Vincent and Brandom, supra note 122.

127. Article 13 of the EU Copyright Directive Threatens the Internet, ELECTRONIC FronTIER FounD. (June 12, 2018), https://perma.cc/37KW-BEJQ. Note that while Article 13 doesn't explicitly require platforms to use automatic filtration to screen for copyright infringement, such technology would be the most effective way for platforms to comply with the new law. 
facto alliance with right holders rather than fearing upstart entrepreneurs." ${ }^{\prime 28}$ Additionally, as discussed previously with regard to Content ID, the platforms might use oversight processes that risk removing non-infringing or fair use content. Article 13 leaves as an open question the extent to which the platforms must consider fair use or other legitimate defenses to infringement before removing content. Still, despite these criticisms, the Copyright Directive would undoubtedly accomplish the protection that creators like Antonio Guillem and Matt Furie sorely need.

For the time being, Congress has made no effort to craft legislation similar to the Copyright Directive. Perhaps this is not entirely a bad thing; Congress can monitor the effects of the Copyright Directive before determining whether the United States should pass a like-minded law and, if so, how to properly balance the interests of rights holders and social media companies. Nonetheless, the current legislative inaction, combined with the ineffectiveness of privately ordered solutions, leaves the American judiciary as the most promising source of increased protection for creators' rights.

\section{JUDGE-MADE COPYRIGHT REFORM USING PERSONAL BRAND PRINCIPLES}

Until recently, American jurisprudence was not encouraging in terms of protecting attribution rights (or even economic rights) of creators operating in digital spaces. But recent developments, both in the courts and in new contexts for old precedent, suggest that the judiciary has the opportunity to take the lead in making room for authors to defend their body of work.

\section{A. Dastar's Loophole and Reviving Trademark Protection of the AtTRIBUtion Right}

When Congress passed the BCIA, existing jurisprudence suggested that the Lanham Act might, in fact, protect various moral rights. The leading pre-BCIA case in this vein is Gilliam v. American Broadcasting Companies, Inc. The dispute centered on ABC's intent to broadcast a version of a comedy special by the British troupe Monty Python that the network had edited significantly for length and content. Monty Python, concerned that the edited special was an inaccurate and inferior presentation of their comedy, filed for an injunction to prevent $\mathrm{ABC}$ from airing the broadcast. The district court judge forced $\mathrm{ABC}$ to display a disclaimer before airing the first comedy special, informing audiences that the work was edited against Monty Python's wishes. Then, the Second Circuit enjoined ABC from broadcasting any subsequent edited version of the troupe's programs. The court's opinion largely rested on two grounds. First, the original contract that Monty Python had signed with BBC (the troupe's British distributor) reserved to Monty Python the rights to its own scripts. $\mathrm{BBC}$ never possessed right to alter the scripts, and thus could not transfer it to $\mathrm{ABC}$ alongside the right to broadcast the comedy specials in the United

128. Nicolas Colin, The EU Copyright Directive Won't Kill the Internet but It Will Kill Startups, FORBES (Sept. 17, 2018, 5:56 AM), https://perma.cc/VJ3U-D2WB. 
States; what $\mathrm{ABC}$ had made through its edits was not a legal abridgement, but an unauthorized derivative work. ${ }^{129}$ Second, and more importantly for attribution rights, the court ruled that the Lanham Act created a right of action in cases where distortion of a creator's work threatened to cause reputational harm to the creator:

[I]t is the writer or performer, rather than the network, who suffers the consequences of the mutilation, for the public will have only the final product by which to evaluate the work. Thus, an allegation that a defendant has presented to the public a 'garbled' . . . distorted version of plaintiff's work seeks to redress the very rights sought to be protected by the Lanham Act . . . and should be recognized as stating a cause of action under that statute. ${ }^{130}$

Gilliam didn't explicitly address an affirmative attribution right, but it did create precedent that copyright owners could use the Lanham Act to prevent distortion of their works if the distorted work was attributed to the original author but varied significantly from the original and if consumers were likely to confuse the two. ${ }^{131}$ Some courts in the three decades following Gilliam expanded its reasoning to allow a "reverse passing off" claim that would force proper attribution of copyrighted works. ${ }^{132}$ This and other developments in intellectual property jurisprudence spurred concern from some commentators that the Lanham Act would grow to become an end run around copyright law, with parties using principles of trademark law to extend protection where copyright couldn't reach. ${ }^{133}$ But the Supreme Court's ruling in Dastar Corp. v. Twentieth Century Fox Film Corp. seemingly ensured that the Lanham Act's use in reverse passing off cases would be significantly limited.

The case arose when Dastar created a home video set called "World War II Campaigns in Europe" using footage from an old World War II television series produced by Fox, which had failed to renew its copyright in the series. ${ }^{134}$ Unable to sue for copyright infringement, Fox instead pursued a reverse passing off claim under the Lanham Act. ${ }^{135}$ The Court took the opportunity to clarify use of the Lanham Act in cases that touched on creative works: a cause of action exists only when there is confusion over the source of the physical goods - that is, the party that produced and delivered them. On the other hand, according to the Court, "[a]s used in the Lanham

129. Gilliam v. Am. Broad. Cos., Inc., 538 F.2d 14, 21 (2d Cir. 1976).

130. Id. at 24-25.

131. See, e.g., Batiste v. Island Records Inc., 179 F.3d 217 (5th Cir. 1999) (granting summary judgment to defendant when plaintiff creator could not "demonstrate the existence of a genuine issue of likelihood of confusion" between the original work and a sampled version); King v. Innovation Books, 976 F.2d 824 (2d Cir. 1992) (holding that a "based upon" credit allowed for audiences to perceive enough difference between a film and the short story upon which it was based so as to avoid a likelihood of confusion).

132. Medea B. Chillemi, Remember My Name: Choreographing the Fit of Section 43 (A) and an Author's Right of Attribution, 14 SETON HALl J. SPORTS \& ENT. L. 517, 529-36 (2004) (describing various tests laid out by U.S. Courts of Appeals to apply the Lanham Act to misattributed creative works).

133. Id.; Stacey M. Lantagne, The Copymark Creep: How the Normative Standards of Fan Communities Can Rescue Copyright, 32 GA. ST. U. L. REV. 459, 470-71 (2016) (noting cases in which plaintiffs attempted to use trademark principles to extend the monopoly granted by copyright).

134. Dastar Corp. v. Twentieth Century Fox Film Corp., 539 U.S. 23, 26 (2003).

135. Id. at 28 . 
Act, the phrase 'origin of goods' is in our view incapable of connoting the person or entity that originated the ideas or communications that 'goods' embody or contain." 136 Because the video set Dastar sold really did come from Dastar, despite containing creative content from a television series that Dastar didn't make, the court denied Fox's reverse passing off claim.

In the wake of Dastar, it is fair to wonder whether the Lanham Act's quasiattribution right usage and the Gilliam lineage still hold water. Some lower courts have attempted to square continued use of the Lanham Act with this dicta by holding that the authorship is not part of the nature of a good. ${ }^{137}$ Another effort has involved lower courts distinguishing between goods and services, allowing for the circumvention of Dastar in the latter category because false attribution for services is likely to have an effect on the injured party's livelihood. ${ }^{138}$ But neither of these legal theories can directly address the fact that the reverse passing off claims that were formerly permissible to protect the proper attribution of creative goods are, after Dastar, no longer viable.

Some might consider this separation of the Lanham Act from copyright to be a good thing. The conflation of copyright and trademark has the potential to overly limit the public domain; for example, the copyright in the television series at issue in Dastar had expired when Dastar made its video set, so a ruling enjoining Dastar's distribution of the works would have effectively given Fox an extended period of copyright protection to which it had no legal right. Additionally, the fair use defense and idea/expression dichotomy serve as bulwarks for free speech only in the copyright sphere; some commentators worry that the use of trademark principles to litigate the traditional sphere of copyright could have a chilling effect on free speech. ${ }^{139}$ But these alarm bells of copyright-trademark conflation seem overblown. Concerns about encroachment upon the public domain could be allayed by nuanced remedies; for instance, if the Dastar court had ruled for Fox but simply ordered Dastar to attribute its videotapes to Fox without enjoining distribution, Fox could not have made an end run around copyright expiration. Furthermore, both the Second and Ninth Circuits have developed balancing tests for cases that involve a work with some artistic merit, weigh the likelihood of consumer confusion against the public interest in free speech and only ruling for the claimant if the former outweighs the latter. $^{140}$ And federal appellate courts have been loath to entertain Lanham Act

136. Id. at 32 .

137. See Lantagne, supra note 133 , at 484.

138. See Gensler v. Strabala, 764 F.3d 735, 736 (7th Cir. 2014).

139. See Lantagne, supra note 133, at 494. The classic Lanham Act test comes from Rogers v. Grimaldi, 875 F.2d 994, 1005 (2d Cir. 1989).

140. See Mattel, Inc. v. Walking Mountain Prods., 353 F.3d 792, 807 (9th Cir. 2003) ("[W]hen marks transcend their identifying purpose and enter public discourse and become an integral part of our vocabulary ... First Amendment protections come into play.") (internal quotations and citations omitted); see also Rogers v. Grimaldi, 875 F.2d 994, 999 (2d Cir. 1989) (construing the Lanham Act "to apply to artistic works only where the public interest in avoiding consumer confusion outweighs the public interest in free expression"). 
claims that would create overlap with copyright law or substantially expand the scope of copyright protection. ${ }^{141}$

Application of the Lanham Act to create an attribution right for a work that is otherwise copyrightable, however, is a different issue entirely. The legislative history of the BCIA, as mentioned supra, explicitly contemplated the Lanham Act as a method by which the attribution right could be added to the suite of rights existing in copyrighted works. Such an expansion of copyright via trademark principle would not be an infringement upon the public domain, because it would not place formerly unprotected works behind a shield. And free speech would be relatively unaffected; merely requiring a fair user to cite their source would hardly chill expression. Most importantly, now that proper attribution has effectively become an economic right in the online arena - and now that it's considered as such by artists working within that space - the Dastar ruling's effect becomes largely negative, unduly harming creators and depriving them of what was, until 2003, a budding attribution right.

But the reconsideration of the attribution right in the context of the digital Grateful Dead model, wherein creative works are given away for free to promote the sale of other products - and, more generally, the idea of creative work as advertisementcould give rise to a Dastar workaround that has not yet been tried. The Dastar court left a hole in its walling off of attribution and integrity claims under the Lanham Act, writing in dicta that "misrepresentation [claims] under the 'misrepresents the nature, characteristics [or] qualities' provision of $\S 43(\mathrm{a})(1)(\mathrm{B})$ [of the Lanham Act]" could still be viable. ${ }^{142}$ Now, $\S 43(a)(1)(B)$ refers specifically to misrepresentation "in commercial advertising or promotion," which at first glance seems to exclude artists' works - traditionally, advertisements lead consumers to the artwork. ${ }^{143}$ But as I have discussed throughout the first Part of this Note, it is possible to interpret at least some creative works as a form of self-promotion - particularly if these works are posted on social media with the goal of engaging a second comer's followers, accumulating more followers, and generally increasing the second comer's presence on the Internet. Courts should reason from a simple starting point: why has the work been displayed on social media? "Sale or licensing of this particular work" could be an answer. This would be the answer in a situation wherein, for example, a second comer passed off a musical recording as their own and had set up a shop, online or brick-and-mortar, to sell the recording; holding that making the recording available constituted an advertisement would conflate all creative goods with promotion, which would expand Lanham Act protection all across the domain of copyrightcertainly an overreach.

On the other hand, if associated hyperlinks (whether in a specific posting or on the user's profile) lead to the user's website rather than a specific forum to license or purchase the work at hand, or if options to like, follow, or subscribe to the user's account are more prominent than options to acquire rights to this particular work, a

141. See e.g., Sybersound Records, Inc. v. UAV Corp., 517 F.3d 1137, 1144 (9th Cir. 2008); Klinger v. Conan Doyle Estate, Ltd., 755 F.3d 496, 497 (7th Cir. 2014).

142. Dastar Corp. v. Twentieth Century Fox Film Corp., 539 U.S. 23, 38 (2003).

143. Lanham Act $\S 43(a)(1)(B), 15$ U.S.C. $\S 1125(a)(1)(B)(2012)$. 
court might reasonably infer that the work's presence on social media is, in fact, promotional. Josh Ostrovsky's Instagram account is a prime example of infringement-as-advertisement. ${ }^{144} \mathrm{He}$ makes no money directly from the unsponsored, stolen jokes and images he publishes - he does not sell them anywhere - but each post garners him hundreds of thousands of likes from his followers, as well as tens of thousands of comments in which followers tag their friends, some of whom may not yet follow Ostrovsky but may be convinced to do so after being enticed to view his account. By thus engaging and cultivating his fan base, Ostrovsky makes himself more attractive to advertisers and corporate brands that are willing to pay him for sponsored posts or pursue joint creative ventures, and he creates a consumer market for products like his own White Girl Rosé wine. ${ }^{145}$ In short, creative works are a promotional tool for Ostrovsky and like-minded social media personae, and misattribution in this context is exactly the type of misrepresentation in commercial advertising and promotion that the Lanham Act contemplates.

Even posts on a user's personal website could potentially be interpreted as selfpromotion if the plaintiff could show that the user had performed search engine optimization (SEO) on the web pages containing the allegedly misattributed or infringing images. SEO is "a marketing discipline focused on growing visibility in organic (non-paid) search engine results," and it is vital to modern digital marketing. One company, Moz, produces a free, 54-page SEO guidebook that it claims has been read more than three million times. ${ }^{146}$ Evidence that the user optimizes their images or text for indexing by search engines might suggest that each individual work is effectively an advertisement that, beyond serving as a creation in its own right, functions to attract fans, advertisers, and potential clients to the user's full body of work and products.

In situations like these, $\S 43(a)(1)(B)$ might apply, particularly if the "nature, characteristics [or] qualities" of the work are interpreted to include integrity of a work or the identity of its author. There appears to be no case law in any federal court regarding the right to integrity, which leaves an opening for a successful Lanham Act claim in cases like the Republican Party's use of "This is Fine" on Twitter, a use to which KC Green objected on moral grounds. ${ }^{147}$ By contrast, there is significant precedent against this interpretation of $\S 43(\mathrm{a})(1)(\mathrm{B})$ with regards to attribution, including a Federal Circuit case explicitly concluding, in an effort to avoid overlap between the Lanham Act and Copyright Act, that "authorship, like licensing status, is not a nature, characteristic, or quality, as those terms are used in Section 43(a)(1)(B) of the Lanham Act." ${ }^{148}$ These cases, however, fundamentally

144. Ostrovsky, supra note 11.

145. Fox, supra note 40.

146. Rand Fishkin \& Moz Staff, The Beginner's Guide to SEO, Moz, https://perma.cc/BRB2YUGK (last visited Feb. 25, 2018).

147. Green, supra note 8.

148. Baden Sports, Inc. v. Molten USA, Inc., 556 F.3d 1300, 1307 (Fed. Cir. 2009); see also Personal Keepsakes, Inc. v. Personalizationmall.com, Inc., No. 11 C 5177, 2012 WL 414803, at *5 (N.D. Ill. Feb. 8, 2012); ZS Assocs., Inc. v. Synygy, Inc. ., No. 10 C 4274, 2011 WL 2038513, at *8-9 (E.D. Pa. May 23, 2011); Sidem, S.A. v. Aquatech Int'l Corp., No 10 C 81, 2010 WL 2573882, at *5-8 (W.D. Pa. Jun. 
misunderstand the dual nature of copyrightable works in the Internet-based attention economy. Using the Lanham Act to enforce attribution rights when a misattributed work is published online without authorization might well conflate advertising and copyright principles - if monetizing the work itself were the economic objective of its publishing. By contrast, when the work functions to promote a user's personal brand, however, it becomes a commercial advertisement or form of promotion - and in passing off the creator's work as their own, the second comer has effectively misrepresented the creator's personal brand. We thus exit the realm of copyright, which exists to protect economic rights to individual works, and enter the realm of the Lanham Act, which exists to protect the economic rights of brands as a means of protecting consumers against deceptive acts in the marketplace. There need not be any overlap. ${ }^{149}$

Whether or not a court would accept an argument that taking credit for others' creative works online is a form of commercial self-promotion is uncertain, and any such argument might need to be supplemented by extensive research into the economic value of social media following and online engagement driven by the gratis publication of copyrightable works but not directly pertaining to the consumption of those works. But given that the Jacobsen court has already recognized the economic benefit of attribution in the context of open-source licensing, the seed of such precedent exists. ${ }^{150}$

\section{B. HOPE For THE DMCA's COPYRIGHT MANAGEMENT INFORMATION Provision}

Nonetheless, using the Lanham Act to enforce attribution rights remains an uphill battle. The most likely other federal statutory source of attribution rights is $\S 1202$ of the Copyright Act. Adopted as part of the DMCA, § 1202 focuses on copyright management information (CMI), which the statute defines to include "identifying information" regarding the title, author, and copyright owner of a work. ${ }^{151}$ In its first section, the statute prohibits the knowing provision and distribution of false CMI with the intent to facilitate copyright infringement. ${ }^{152}$ In its second section, the statute prohibits the removal of CMI:

No person shall, without the authority of the copyright owner or the law, (1) intentionally remove or alter any copyright management information, (2) distribute or import for distribution copyright management information knowing that the copyright management information has been removed or altered without authority of the

23, 2010); Antidote Int'l Films, Inc. v. Bloomsbury Publ'g, PLC, 467 F.Supp.2d 394, 400 (S.D.N.Y. 2006) (collecting cases saying the same).

149. Furthermore, even if a court were to consider this to be overlap between copyright and advertising law, what of it? Congress itself stated that the Lanham Act would be used to ensure that the United States adhered to the Berne Convention; rigid, formalistic distinctions between the Copyright Act and the Lanham Act serve to undermine American commitment to protecting the full scope of copyright as adopted by Congress when it implemented Berne. See Ginsburg, supra note 100.

150. Jacobsen v. Katzer, 535 F.3d 1373, 1381 (Fed. Cir. 2008).

151. 17 U.S.C. $§ 1202(\mathrm{c})(1-3)(1998)$.

152. 17 U.S.C. $\$ 1202(a)(1998)$. 
copyright owner or the law, or (3) distribute, import for distribution, or publicly perform works, copies of works, or phonorecords, knowing that copyright management information has been removed or altered without authority of the copyright owner or the law, knowing, or, with respect to civil remedies under section 1203, having reasonable grounds to know, that it will induce, enable, facilitate, or conceal an infringement of any right under this title. ${ }^{153}$

With regard to the digital images that form the backbone of most memes (and are creative works in themselves), the relevant CMI may be contained in metadata. Metadata can be attached to an image either manually or automatically, and it can include various information about the image: its name, its creator, where and when it was taken or created (and by what camera), et cetera. ${ }^{154}$ In some file formats, like the ubiquitous JPEG, metadata is embedded in the image file itself, so a JPEG's metadata should stay affixed to the image no matter how many times, and to what destinations, the image is uploaded or downloaded. ${ }^{155}$ Theoretically, therefore, metadata should be a powerful tool for exercising the attribution right. All a photographer or digital artist need do would be to attach his or her name to the image using metadata, and then $\S$ 1202(b) would prevent anyone from removing the attribution.

The issue is that metadata is often stripped from images upon their upload to social media. According to a 2015 study conducted by the International Press Telecommunications Council (IPTC), many of the most popular social media platforms - Instagram, Twitter, Tumblr, Facebook - do not preserve the metadata containing copyright management information when their users post images. ${ }^{156}$ Additionally, even if a user has managed to upload a photo to these platforms with CMI metadata intact, the metadata is stripped when viewers save photos from Twitter and Tumblr onto their own local drives (Facebook only partially preserves the metadata during this process). ${ }^{157}$ So when a photo like Antonio Guillem's "Distracted Boyfriend" is uploaded to a Facebook group as a meme, the data stating that Guillem took the photo and that either he or iStock owns the copyright disappears. The meme spreads like wildfire, but without some journalistic digging, Guillem languishes in obscurity. And if he chooses to attempt to find all copies of his photograph floating around online, perhaps to ask users to provide a link to a webstore he might set up, the lack of metadata severely hampers his search ability.

Finding individual users responsible for stripping CMI-containing metadata from digital images would be nearly impossible. For this reason, effective enforcement needs to take place at the platform-wide level. The courts here have recently taken an encouraging turn. In Friedman v. Live Nation Merchandise, Inc., the Ninth

153. 17 U.S.C. § 1202(b) (1998).

154. What Is Photo Metadata?, INT'L PRESS TELECOM. COUNCIL, https://perma.cc/93RK-K772 (last visited Feb. 25, 2018).

155. Id.

156. Embedded Metadata Manifesto, Social Media Sites Photo Metadata Test Results, INT'L PRESS TELECOM. COUNCIL, https://perma.cc/T75N-S5YY (last visited Feb. 25, 2018). Note that the test's mentions of EXIF metadata are irrelevant for the purposes of this Note, as EXIF does not contain CMI.

157. Id. 
Circuit reversed the district court's grant of summary judgment for a merchandising company that had used copies of a photographer's work from which CMI had been removed. The court first noted that "Friedman could [] prevail upon a showing that Live Nation distributed his works with the knowledge that CMI had been removed, even if Live Nation did not remove it." 158 Then, after pointing out evidence that appeared to indicate the exact authorized online user from whom Live Nation copied the photos, the court wrote, "[b]ecause the only material difference in the Live Nation versions was that the CMI was missing, it was necessarily the case that the CMI had been removed on the copied version." Finally, and most importantly, the court used broad language in ruling that Live Nation could not defeat the instant $\S 1202$ (b) claim at summary judgment: "The only question, then, is whether the evidence as a whole permits a reasonable inference that Live Nation knew of the removal of the CMI. As to this question, a reasonable jury could certainly conclude that Live Nation had knowledge that photographs are often copyrighted." 159

The rhetoric of Friedman seems to open the door for suits that target social media platforms under $\S 1202(\mathrm{~b})(2)$ or (3), particularly because these platforms know that their processes automatically strip metadata from uploaded images. Professor Ginsburg writes,

[I]f the platform processes the uploads through a program that the platform knows will excise CMI-bearing metadata, it should not matter that the removal is automatic and indiscriminate; setting the default to eliminate embedded metadata, assuming this is a desired result and not merely an unanticipated by-product of some other function, represents a choice by the platform. ${ }^{160}$

Even if this were not interpreted as intentional removal of CMI under § 1202(b)(1)and it reasonably could be - copyright plaintiffs could at least prove that the platforms know about the removal of CMI, just as Live Nation did in Friedman. That said, these plaintiffs would have to clear a second hurdle of proving either that, under (b)(2), the social media platforms serve as distributors of the images or that, under (b)(3), they knew that their public display of the images was facilitating copyright infringement. The latter claim might be hard to prove, because knowledge must typically pertain to specific infringement. ${ }^{161}$

In any regard, no court has yet heard a $\S 1202$ case brought against a social media platform, let alone since Friedman, and such a case might never come about because of the high cost of litigation for photographers and artists. ${ }^{162}$ Additionally, even if the integrity of CMI were more strictly enforced, it still might not solve the

158. Friedman v. Live Nation Merch., Inc., 833 F.3d 1180, 1187 (9th Cir. 2016).

159. Id. at 1188 .

160. Ginsburg, supra note 100 , at 68 .

161. See Viacom Int'l, Inc. v. YouTube, Inc., 676 F.3d 19, 30 (2d Cir. 2012). Note, however, that a solution to this problem exists; it is detailed in Part III(C), infra.

162. In fact, only one case has even cited Friedman's 1202(b) precedent: Fischer v. Forrest, 14 Civ. 1304 (PAE) (AJP) 2017 WL 2992663 (S.D.N.Y. July 14, 2017). But the Fischer court never had to reach the issue of whether the defendant's knowledge of metadata-stripping processes sufficed to constitute a 1202 (b) violation, because the plaintiff never submitted evidence that the original work had contained CMI. Fischer, 2017 WL 2992663 at *17, *19. 
attribution right problem as it pertains to ordinary consumers of digital images, who might not know to look for CMI in the "properties" of the image. Nonetheless, more sophisticated actors, like corporations and social media platforms themselves, would not have any excuse to improperly attribute works - or to avoid paying their creators - if courts were to follow the promising lead of Friedman and hold that automatic processes that strip CMI metadata violate $\S 1202$ (b).

\section{Protecting Creators' Economic Power with Takedown-Staydown}

If copyright law for online artists is to move in the direction of brand protectionselling the artist, not the art-social media platforms will have to be made liable for violations of authors' rights beyond those CMI-related rights delineated in $\S 1202$. The norms of Internet culture do not suggest that users will cease to share images they are not authorized to reproduce, distribute, or display. Any attempt to categorically enjoin such behavior would not only be practically impossible, but it would also spark mass outrage as a significant threat to freedom of expression and eliminate the positive value that social media viral DNA contributes to society. On the other hand, social media companies, with their deep pockets and omnipresent role in allowing the spread of online works, make attractive targets for suits seeking to change the way creative intellectual property is protected on the Internet. I have highlighted existing legal principles and judicial precedents that might plant the seeds for an attribution right to grow, but in order for artists to pursue the second crucial step of personal branding - monetization of their body of work - they still need the ability to enforce traditional economic rights of copyright. Such rights also provide an important backstop for those online creators whose field of work does not lend itself well to fan engagement or brand creation.

One encouraging development in this area of law is the potential for "take-down stay-down," an interesting reimagining of the DMCA's notice and takedown procedure. 17 U.S.C. $\S 512$ grants safe harbor to online service providers (OSPs), so long as they act "expeditiously" to remove infringing material stored on their site upon receiving actual or so-called "red flag" knowledge of the infringement whether of their own accord or via notice given them by copyright owners. ${ }^{163}$ Until recently, the most thorough discussion of $\S 512$ came in Viacom Int'l, Inc. v. YouTube, Inc., in which Viacom attempted to enjoin YouTube for hosting tens of thousands of videos that infringed Viacom's content. Among the most important aspects of the case was the court's ruling that attacks on an OSP's safe harbor could only occur if the OSP had actual or red flag knowledge of a specific infringing activity: "[T]he nature of the removal obligation itself contemplates knowledge or awareness of specific infringing material, because expeditious removal is possible only if the service provider knows with particularity which items to remove." 164 Because OSPs also do not have an affirmative duty to monitor for infringement, the effect of Viacom appeared to be that plaintiffs would bear the enormous burden of needing to find

163. 17 U.S.C. $\$ 512(c)(1)(2012)$.

164. Viacom, 676 F.3d at 30. 
every individual infringement of their works on a given OSP and send notice of each. ${ }^{165}$ But just four years later, the Second Circuit heard EMI Christian Music Group, Inc. v. MP3tunes, $L L C$, a case regarding a website that offered "lockers" for users to store free music found on the Internet. ${ }^{166}$ The court used this case as an opportunity to turn the tables back on the OSPs. The bulk of the court's focus concerned "repeat infringers," users of MP3tunes' services who were repeatedly the subject of takedown notices and yet did not have their accounts terminated by the site's administrators. ${ }^{167}$ But the most important part of the opinion explained that requiring MP3tunes to terminate these accounts "would not require MP3tunes to 'monitor' or 'affirmatively seek facts' about infringing activity in a manner inconsistent with $\S 512(\mathrm{~m})(1)$ because it already had adequate information at its disposal in the form of takedown notices provided by EMI as to which links were allegedly infringing." 168 The court then wrote, "MP3tunes would simply have had to make use of information already within its possession and connect that information to known users."169

This method of proving actual or red flag knowledge of infringement by or on OSPs could serve as a vital construction of the safe harbor provisions of $\S 512$ (c) with regard to creative works posted to social media, particularly if jurisprudence post-Friedman moves in the direction that requires the platforms to maintain the integrity of CMI. The inclusion of CMI, specifically via metadata, would grant social media platforms information about the copyrighted works being hosted on their platforms - and about the infringing copies. So, if a creator were to file a takedown notice against a specific infringing copy of their work, the reasoning of $E M I$ Christian suggests that the social media platform, now having recognized that copy as unauthorized, would be held to have knowledge that it's a copyright infringement any subsequent time it was uploaded. Like antibodies recognizing a returning strain of bacterium, the platform's upload process would now have to include a mechanism either to block or to instantly flag any post previously marked as an infringement. The upshot is that artists like Matt Furie could slowly but decisively eliminate perversions or unattributed versions of their work via DMCA takedown notices, one at a time, with the knowledge that each individual infringement could never return to that particular platform. ${ }^{170}$ With some effort, artists could ensure that any

165. 17 U.S.C. $§ 512(\mathrm{~m})(2012)$. This lack of affirmative duty to monitor is couched in the language of privacy protection.

166. EMI Christian Music Grp., Inc., v. MP3tunes, L.L.C., 844 F.3d 79, $86-87$ (2d Cir. 2016).

167. Id. at $90-91$.

168. Id. at 91 .

169. Id.

170. Of course, the copyright owner would have to undertake a good faith consideration of whether the infringing work was protected by fair use, as some second comers would surely file a counter-notice and defend their use of the work. See Lenz v. Universal Music Corp., 815 F.3d 1145, 1153-54 (9th Cir. 2015) ("Universal faces liability if it knowingly misrepresented in the takedown notification that it had formed a good faith belief the video was not authorized by the law, i.e., did not constitute fair use."). 
unauthorized versions of their works published to social media sites at least grant them proper credit and do not harm the value of their personal artistic brand. ${ }^{171}$

A problem remains, though: the pursuit of infringing works via DMCA notice and takedown is time-consuming, especially for individual actors who lack the resources or technical know-how of large, corporate copyright holders. One practical solution here might be the creation of a digital artists' rights organization to file DMCA notices and collect royalties from uses of the works. Given the rather libertarian ethos of the Internet as exemplified by creators like KC Green, it seems unlikely that digital artists would ever want to join a massive rights-collecting society with compulsory licenses in the vein of ASCAP or BMI. ${ }^{172}$ But there is room for an organization that would hunt for infringements and negotiate license fees in exchange for a small commission, particularly for artists in industries (i.e. stock photography) that are not as amenable to the creation of a personal brand and thus depend more upon traditional economic benefits of copyright. ${ }^{173}$

\section{CONCLUSION: THE POSITIVE FEEDBACK OF RIGHTS EXTENSION}

If practicalities were no object, the ideal situation for online copyrighted works would involve a technology that displays creators' names inextricably beside their creations and, upon a user's click, would direct the user to the creator's personal website, social media profile, or online store. Attempts at creating such a technology have flailed thus far. ${ }^{174}$ But if American jurisprudence moves in the direction outlined in this Note, privately ordered solutions would have a smaller gap to cover, and as creators gain more power, social media platforms and other websites might become more responsive to their demands.

The Southern District of New York's recent decision in Goldman v. Breitbart News Network, $L L C$, while unrelated to personal branding principles, might signal coming empowerment of Internet-based creators. ${ }^{175}$ In finding that several news websites had infringed copyright by embedding on their web pages a tweet containing Goldman's photo, the court rejected the so-called "server test" developed

171. The argument presented in this paragraph might also apply to search engines, which receive safe harbor under the DMCA's $\S 512(\mathrm{~d})$. Google's robots.txt, which crawl the web to index sites such that they appear in search results, are capable of reading image metadata; see Search Console Help, Meta Tags that Google Understands, GoOGLE, https://perma.cc/V9H3-R56N. If a court decides that this information is in Google's possession, then Google could be responsible for excluding repeat-infringing images from its image searches.

172. Both ASCAP and BMI are subject to consent decrees that control the royalty rates they can charge for public performance of musical works. See ASCAP - BMI Consent Decrees, FUTURE OF MUSIC COALITION (Aug. 4, 2016), https://perma.cc/8V2V-7JXA.

173. See Part II(C), supra (discussing the Music Licensing Collective). That said, a similar organization dealing with digital images would presently be harder to set up, as social media platforms in the United States-here analogous to music streaming services - don't currently have the legal or economic incentive to fund a licensing collective.

174. Supra note 121.

175. 302 F. Supp. 3d 585 (S.D.N.Y. 2018). 
in Perfect 10 v. Amazon.com, Inc. ${ }^{176}$ The server test dictates that "whether a website publisher is directly liable for infringement turns entirely on whether the image is hosted on the publisher's own server, or is embedded or linked from a third-party server." 177 In countering the server test, the Southern District, citing the Supreme Court's pragmatic opinion in $A B C$, Inc. v. Aereo, Inc. ${ }^{178}$ first reasoned that "liability should not hinge on invisible, technical processes imperceptible to the viewer."179 Then, the court explicitly disagreed with Perfect 10, stating that it found "no indication in the text or legislative history of the [Copyright] Act that possessing a copy of an infringing image is a prerequisite to displaying it." 180

Goldman is the type of decision that, were it affirmed by the Second Circuit, could drastically alter the balance of power between creators and users; by shutting down the free process of embedding, the court would likely force more users to pay for licenses for the images they intend to use. With the economic prospects of photographers and other digital artists thus improved, these creators would have more incentive to vigorously defend their rights and monetize their content. And for the business-savvy creator, such monetization would likely involve a robust effort to maintain a web presence, promote their works, and actively seek out more potential licensing clients - that is, the pursuit of a personal brand. The more the economic realities of the Internet encourage creators to take such steps, the more powerful the legal arguments I laid out in this Note will become.

So, is everything really fine right now in the world of online creativity? Not yet. But if recent judicial precedent is any indication, the artist's way of life looks less like it's going up in flames.

176. 508 F.3d 1146 (9th Cir. 2007).

177. Goldman v. Breitbart News Network, L.L.C., 302 F. Supp. 3d 585, 590 (S.D.N.Y. 2018).

178. 134 S. Ct. 2498 (2014).

179. Goldman, 302 F. Supp. 3d at 595.

180. Id. 